\title{
SUPRA-PHYSIOLOGICAL LEVELS OF GIBBERELLINS / DELLAS MODIFY ROOT CELL SIZE / NUMBER AND ROOT ARCHITECTURE IN ROOT TIPS OF ARABIDOPSIS THALIANA SEEDLINGS. CONNECTIONS TO THE ROOT HAIR PATTERNING AND ABUNDANCE
}

\author{
Iva MCCARTHY-SUÁREZ
}
Hormone Signalling and Plant Plasticity Group. Instituto de Biología Celular y Molecular de Plantas (IBMCP-UPV-CSIC). Ingeniero Fausto Elio s/n (46022), Valencia - Spain.
E-mail: ivmcsua@upvnet.upv.es

\begin{abstract}
A previous study showed that excessive GAs/DELLAs altered the arrangement, shape and frequency of hairs in root tips of $A$. thaliana seedlings by acting from the root sub-epidermal tissues. The present study showed that excessive GAs/DELLAs also modified root tip cell size/number in $A$. thaliana seedlings. While excessive DELLAs shortened and widened the root epidermal, cortical, endodermal and pericycle cells, excessive GAs, excepting the epidermal cells, generally narrowed them. However, no root cell size changes occurred when gai-1 was over-expressed at the root epidermis. Also, excessive DELLAs induced extra cells at the root epidermis, cortex, endodermis and pericycle and lateral root outgrowth, whereas excessive GAs induced extra cells at the root cortex and pericycle. Thus, excessive GAs/DELLAs might modify root tip cell size/number by acting from the sub-epidermal tissues of the root. This, in turn, might impact on the root hair patterning \& abundance and the root architecture.
\end{abstract}

Keywords: DELLAs, Gibberellins, lateral roots, root architecture, root cell number, root cell size.

\section{Introduction}

A previous study showed that supra-physiological levels of GAs/DELLAs altered the patterning, the morphology and the abundance of root hairs in A. thaliana seedlings, and that they did it by possibly acting from the sub-epidermal tissues of the root [MCCARTHYSUÁREZ, unpublished manuscript]. In fact, the GAs/DELLAs have a role in the production of trichomes (leaf hairs) in A. thaliana [CHIEN \& SUSSEX, 1996; TRAW \& BERGELSON, 2003] and participate in the organization of the cytoskeleton of microtubules (MT) [LOCASCIO $\&$ al. 2013], which is essential for trichome and root hair growth, for establishing root cell identity and shape, and for plant cell expansion and division [BAO \& al. 2001].

Because auxin, ethylene, abscisic acid, nitric oxide, brassinosteroids, cytokinins and strigolactones regulate the root hair patterning [CAO \& al. 1999; VAN HENGEL \& al. 2004; LOMBARDO \& al. 2006; KAPPUSAMY \& al. 2009; NIU \& al. 2011], and because changes in the levels of these phytohormones are correlated to alterations in the root cell size/number and the root architecture in response to nutritional stresses, such as low availability of $\mathrm{P}, \mathrm{B}$ or $\mathrm{Fe}$ in the soil (e.g. swelling of root cortex cells, induction of extra cells at the root cortex, and production of lateral roots (LR)) [SCHMIDT \& al. 2000; YANG \& al. 2007; MARTÍNREJANO \& al. 2011], this study wanted to determine whether supra-physiological levels of GAs/DELLAs might also have an effect on the size/number of root cells and on the production of LR in root tips of $A$. thaliana seedlings. To this aim, the size and/or number of root tip cells 
were examined in Col (0) seedlings grown for 5 days under excessive levels of GAs/DELLAs, as well as in GAs ( $Q D, 5 X$, GID1b-ox) or DELLAs (gai-1, HSp::gai-1, pGAI::gai-1:GR, SCR::gai-1:GR)-overproducing mutants. Moreover, the size of root tip cells was examined in 5-day-old mutant seedlings resulting from expressing the gai-1 (GA-insensitive) DELLA allele in different tissues of the root (UAS (GAL4-UPSTREAM ACTIVATION SEQUENCE) expression directed system lines; Dr. JIM HASSELHOFF'S laboratory). On the other hand, the presence of LR was also analysed in root tips of $A$. thaliana seedlings grown under (or harbouring) excessive levels of GAs/DELLAs. Results of this study suggested that the GAs/DELLAs might have a role in regulating the size, number and organization of root cells, as well as the root architecture, in root tips of A. thaliana seedlings.

\section{Material and methods}

\section{Plant Material and Growth Conditions}

Arabidopsis thaliana Col (0) seeds were sterilized (70\% Ethanol (v/v) and $0.01 \%$ Triton X-100 (v/v)), sown on half-strength MS medium plates $(0.8 \%(\mathrm{w} / \mathrm{v})$ agar and $1 \%(\mathrm{w} / \mathrm{v})$ sucrose), stratified for 3-4 days $\left(4^{\circ} \mathrm{C}\right.$, darkness), germinated, and grown vertically $\left(22{ }^{\circ} \mathrm{C} ; 5-7\right.$ days) under continuous white light (Percival growth chamber E-30B) (http://www.percivalscientific.com) as described by LEE \& SCHIEFELBEIN (1999).

\section{Hormone and Chemical treatments}

Stock solutions of paclobutrazol (PAC, $10 \mathrm{mM}$ in acetone $100 \%(\mathrm{v} / \mathrm{v})), \mathrm{GA}_{4}(1 \mathrm{mM}$ in $100 \%$ ethanol $(\mathrm{v} / \mathrm{v}))$ or $\mathrm{GA}_{3}(50 \mathrm{mM}$ in $100 \%$ ethanol $(\mathrm{v} / \mathrm{v}))$ were conveniently diluted and added to MS agar medium or water (in the case of liquid incubation experiments) to obtain a final concentration of $0.5 \mu \mathrm{M} \mathrm{PAC}, 1 \mu \mathrm{M} \mathrm{GA}_{4}$ and $30 \mu \mathrm{M} \mathrm{GA}_{3}$.

\section{Mutant Lines}

In a previous study [MCCARTHY-SUÁREZ, unpublished manuscript], the spatial gene expression of the root non-hair epidermal cell fate marker GL2 was studied in root tips of A. thaliana seedlings by using the GL2pro::GUS mutant line as well as those derived from crossing lines harbouring constitutively excessive levels of GAs/DELLAs with the GL2pro::GUS line (Ler x GL2pro::GUS background). In the present study, the effect of transient increases in the levels of expression of the gai-1 (GA-insensitive-1) DELLA alelle on the size and number of root tip cells in A. thaliana seedlings was examined by using the gai-1 mutant lines of heat-shock inducible HSp::gai-1 (which over-expresses gai-1 upon heat shock) and of dexamethasone (DEXA)-inducible pGAI::gai-1:GR and SCR::gai-1:GR (with glucocorticoid-binding domain). The HSp::gai-1 mutant seedlings were grown at $37^{\circ} \mathrm{C}$ for $4 \mathrm{~h}$ (heat-shock) and then at $22^{\circ} \mathrm{C}$ for $2 \mathrm{~h}$ (recovery period), whereas the pGAI::gai-1:GR and SCR::gai-1:GR mutant seedlings were incubated in $0.2,1.2$ or $10 \mu \mathrm{M}$ DEXA for a minimum of 6h. Root cell size and number was also studied in mutants with excessive levels of GAs/DELLAs (gai-1, QD (quadruple DELLA mutant), 5X (quintuple DELLA mutant) and GID1b- $o x$ (which over-expresses the GA receptor GID1b (GIBBERELLIN INSENSITIVE DWARF1)), in mutants over-expressing gai-1 in different tissues of the root (ML1::gai-1 (epidermis) and UAS expression directed system (GAL4-UPSTREAM ACTIVATION SEQUENCE) lines: UAS::gai-1 x C24 (control, background); UAS::gai-1 x J0951 (epidermis of the meristematic zone (MZ)); UAS::gai-1 x J2812 (MZ epidermis and cortex); UAS::gai-1 $\mathrm{x}$ N9142 (cortex of elongation zone (EZ)); UAS::gai-1 x M0018 (MZ cortex and endodermis); 
UAS::gai-1 x J0571 (MZ cortex and endodermis); UAS::gai-1 x Q2393 (all tissues but the endodermis); UAS::gai-1 x Q2500 (MZ endodermis/pericycle); UAS::gai-1 x J0121 (EZ pericycle); UAS::gai-1 x J0631 (all tissues of the EZ); UAS::gai-1 x J3281 (vessels)), and in the $35 S: \because C P C \times$ GL2pro::GUS and scm (scrambled) x GL2pro::GUS mutants.

\section{GUS activity assay}

GUS ( $\beta$-glucuronidase) staining of the GL2pro::GUS reporter line was performed as described by FRIGERIO \& al. (2006), but using $8 \mathrm{mM}$ instead of $2 \mathrm{mM}$ potassium ferro/ferricyanide and incubating the seedlings $(15 \mathrm{~min}$ to $2 \mathrm{~h})$ in the reaction mixture at $4{ }^{\circ} \mathrm{C}$ instead of $37^{\circ} \mathrm{C}$.

\section{Microscopy}

Cell organization at the root tip was studied on ultra-thin cross sections of plastic resinembedded roots as described by Dr. SCHIEFELBEIN Protocols (http://www.mcdb.lsa.umich.edu/labs/schiefel/protocols.html). Seedlings were included in 1\% agarose in $0.1 \mathrm{M}$ sodium phosphate buffer, $\mathrm{pH} 6.8$, and stained for GUS activity. Rootcontaining blocks were then cut, fixed with $4 \%$ para-formaldehyde in PBS, dehydrated in ethanol series $(15 \%, 30 \%, 50 \%, 75 \%, 95 \%$ and 100\%, $1 \mathrm{~h}$ each), kept in $100 \%$ ethanol overnight, incubated in Technovit $® 7100$ infiltration solution for 2 days, inserted in gelatine capsules, and embedded for 9 days in Technovit ® 7100 plastic resin (Heraeus Kultzer, Germany). Ultramicrotome (Ultracut E, Reichert Jung, Germany) cross sections of resinembedded roots were then stained with $0.06 \%(\mathrm{w} / \mathrm{v})$ toluidine blue and observed under a Nikon Eclipse E600 microscope. The GFP expression in HASELHOFF's crossed lines was visualized by using a Leica Confocal Microscope (Excitation: $488 \mathrm{~nm}$; Detection: 500-530 nm band-path filter for GFP).

\section{Results}

\section{Excessive levels of GAs/DELLAs modified the size and number of root tip cells in seedlings of $A$. thaliana}

Apart from altering the patterning, morphology and abundance of root hairs [MCCARTHY-SUÁREZ, unpublished manuscript], high levels of GAs/DELLAs also modified the size and number of root tip cells in seedlings of $A$. thaliana (Figures 1-3; Tables 1-3). While excessive levels of GAs, excepting the epidermal cells, usually narrowed the root cells, excessive levels of DELLAs frequently widened, shortened and twisted the root epidermal, cortical, endodermal and pericycle cells, resulting in wider roots (Figures 1-3; Tables 1-3). Moreover, in the HSp::gai-1 and SCR::gai-1:GR mutants, the widening and shortening of the root epidermal, cortical, endodermal and pericycle cells observed at $24 \mathrm{~h}$ after heat-shock $\left(37^{\circ} \mathrm{C}\right.$, $4 \mathrm{~h}$ ) or after growth in DEXA $(10 \mu \mathrm{M})$, respectively (Figure 3), was accompanied, as previously reported [MCCARTHY-SUÁREZ, unpublished manuscript], by an alteration in the spatial expression of GL2 and in the distribution of root hairs. Similar changes were observed when gai-1 was over-expressed at the subepidermal tissues of the root (Figures 1, 2 and 4; Table 1). However, when gai-1 was over-expressed at the root epidermis, no apparent changes occurred in the size of the root epidermal, cortical, endodermal or pericyclic cells (Figures 1, 2 and 4; Table 1), in the patterning of GL2 gene expression or in the root hair distribution [MCCARTHYSUÁREZ, unpublished manuscript], what suggested that the changes in root cell size that took place when gai-1 was over-expressed at the sub-epidermal tissues of the root might have been 
connected to the alterations in the root hair patterning induced by excessive levels of GAs/DELLAs.

Growth of A. thaliana seedlings for 5 days under excessive levels of GAs, in contrast, caused the narrowing of the root cortical cells, an effect that was corroborated in the $Q D, 5 X$ and GID1b $o x$ mutants (Figure 2; Table 1). Nevertheless, excessive levels of GAs also seemed to slightly increase the relative width of the root epidermal cells (Figures 1, 5 and 6). Frequently, under $\mathrm{GA}_{3}(30 \mu \mathrm{M})$ or $\mathrm{GA}_{4}(1 \mu \mathrm{M})$, changes of cell fate at the root epidermis coincided with changes in the width of the epidermal cells and/or with changes in the size of the root cortical and endodermal cells (Figure 3; Tables 1 and 2).

In fact, estimations of tissue depth in root tips of $A$. thaliana seedlings uncovered the swelling of the root epidermal, cortical, endodermal and pericyclic cells under high levels of DELLAs (PAC) and their slight thinning under high levels of GAs (5X mutant) (Table 4). Moreover, growth of seedlings of the scm x GL2pro::GUS mutant in PAC $(0.5 \mu \mathrm{M})$ for $5 \mathrm{~d}$ caused the radial swelling of the epidermal, cortical and endodermal and pericyclic cells of the root tip (Figure 6). On the other hand, in seedlings of the $35 S: \because C P C \times$ GL2pro::GUS mutant, changes of cell fate at the root epidermis were accompanied by changes in the width of the underlying root epidermal and cortical cells (Figure 3).

Interestingly, cell size changes in root tips under excessive levels of GAs/DELLAs were often accompanied by the presence of multinucleated cells at the epidermis, cortex, endodermis and pericycle of the root (Figure 6).

Excessive levels of GAs/DELLAs also modified the radial cell organization in root tips of A. thaliana seedlings (Figure 5). Treatments with PAC $(5 \mathrm{~d}, 7 \mathrm{~d})$ frequently increased the number of cells at the epidermis, cortex, endodermis and pericycle of the root (Figures 5 and 6; Table 5) and induced anticlinal/diagonal cell divisions at the root epidermis (T-clones) (Figure 3 ) as well as periclinal cell divisions at the root cortex and endodermis (middle cortex (MC)) (Figure 6). Furthermore, growth of the scm x GL2pro::GUS mutant for 5 days in PAC induced the proliferation of the root epidermal, cortical and endodermal cells and the formation of a MC (Figure 6). Treatments with excessive levels of GAs, in turn, sometimes increased the number of cortical and pericycle cells, but not of epidermal cells, in the radial dimension of the root, and induced epidermal T-clones and a MC (Figures 3, 5 and 6; Table 5). Moreover, the number of root epidermal cells decreased in the $5 X$ mutant (Figure 5; Table 5), which, in part, might have explained the lower abundance of root hairs per root radial section in this mutant [MCCARTHY-SUÁREZ, unpublished manuscript]. In fact, in root cross sections, frequently only one epidermal cell was seen at the Atrichoblast (non-hair) position under high levels of GAs, whereas up to four cells could be seen under high levels of DELLAs (Figure 5), in tune with the reduced number of epidermal cells in the $5 X$ mutant and the increased number of epidermal cells under PAC (Table 5). Furthermore, given that root non-hair cells lay over just one cortical cell, then, the observed increase in the width of the cortex cells under high levels of DELLAs (Figures 2, 4 and 5; Table 1) might have accounted for the higher percentage of epidermal cells at the Atrichoblast position, as well as the lower percentage of epidermal cells at the Trichoblast position, detected per root radial section under this treatment [MCCARTHYSUÁREZ, unpublished manuscript]. Conversely, the decrease in the width of the cortex cells seen under high levels of GAs ( $5 X$ mutant) (Figure 2; Table 1) might have explained the lower percentage of epidermal cells at the Atrichoblast position, and the higher percentage of epidermal cells at the Trichoblast position, found per root radial section under this treatment [MCCARTHY-SUÁREZ, unpublished manuscript]. Nevertheless, considering that the average number of epidermal cells per root radial section increased under high levels of DELLAs (PAC, 
Iva MCCARTHY-SUÁREZ

gai-1) and decreased under high levels of GAs (5X mutant) [MCCARTHY-SUÁREZ, unpublished manuscript], then, the predicted number of epidermal cells at the Trichoblast position did not change under excessive levels of GAs/DELLAs in 5 day-old A. thaliana seedlings [MCCARTHY-SUÁREZ, unpublished manuscript].

The root diameter at the MZ, in addition, increased by $40 \%$ under excessive levels of DELLAs (Table 3), in tune with the increased number of cells at the root epidermis, cortex, endodermis and pericycle (Figure 5; Table 5) and the wider and/or deeper cells at the root cortex, endodermis and pericycle (Figures 5 and 6; Tables 1 and 4). Conversely, under excessive levels of GAs, the root diameter decreased (Table 3), in accordance with the lower number of cells at the root epidermis ( $5 X$ mutant) (Table 5), and the narrower and shallower cells at the root cortex and endodermis (Figures 2, 5 and 6; Tables 1 and 4). Nevertheless, at the MZ-EZ transition zone, the root also seemed to swell under excessive levels of GAs, and there was variability of cell sizes [MCCARTHY-SUÁREZ, unpublished manuscript] (Figure 6), maybe due to the swelling of the epidermal cells and to the deepening of the pericycle cells (Figure 1; Table 4). In fact, $\mathrm{GA}_{3}$ treatments increase the ratio of (xylem/whole root) area [WANG \& al. 2015].

\section{Excessive levels of GAs / DELLAs modified the outgrowth of lateral roots in root tips of $A$. thaliana seedlings}

Excessive levels of DELLAs also induced the outburst of LR near the root tip in $A$. thaliana seedlings, whereas excessive levels of GAs inhibited it (Figure 7).

Table 1. Average length and width of root cortical cells in root tips of 5-day-old A. thaliana seedlings grown under (or harbouring) excessive levels of GAs/DELLAs. Analyses performed on micrographs of root cortex cells, 20X. (*) At 48h after a 4h-heat-shock experiment.

\begin{tabular}{|c|c|c|c|c|}
\hline & \multicolumn{4}{|c|}{ Root cortical cell } \\
\hline & $\begin{array}{l}\mathbf{N}^{0} \text { Cells } \\
\text { analysed }\end{array}$ & Length $(\mu \mathrm{m})$ & $\begin{array}{l}\mathrm{N}^{0} \text { Cells } \\
\text { analysed }\end{array}$ & Width $(\mu \mathrm{m})$ \\
\hline Col (0) (MS) & 25 & $171 \pm 28(100 \%)$ & 66 & $31 \pm 3(100 \%)$ \\
\hline $\operatorname{PAC}(0.5 \mu M)$ & 23 & $153 \pm 34(89 \%)$ & 60 & $43 \pm 3(142 \%)$ \\
\hline $\mathrm{GA}_{4}(1 \mu \mathrm{M})$ & 26 & $209 \pm 52(122 \%)$ & 26 & $27 \pm 2(87 \%)$ \\
\hline $\mathrm{PAC}(0.5 \mu \mathrm{M})+\mathrm{GA}_{4}(1 \mu \mathrm{M})$ & 24 & $173 \pm 49(101 \%)$ & 28 & $19 \pm 2(61 \%)$ \\
\hline Ler & 28 & $188 \pm 29(100 \%)$ & 18 & $30 \pm 4(100 \%)$ \\
\hline ML1::gai-1 & 12 & $171 \pm 33(91 \%)$ & 28 & $30 \pm 3(97 \%)$ \\
\hline gai-1 & 71 & $138 \pm 41(73 \%)$ & 72 & $37 \pm 7(123 \%)$ \\
\hline$Q D$ & 33 & $180 \pm 34(96 \%)$ & 53 & $27 \pm 3(90 \%)$ \\
\hline $5 X$ & 15 & $187 \pm 34(99 \%)$ & 30 & $27 \pm 4(90 \%)$ \\
\hline GIDIb-ox & 23 & $210 \pm 54(112 \%)$ & 34 & $24 \pm 4(80 \%)$ \\
\hline $\begin{array}{l}\text { Hsp::gai-1x GL2pro::GUS } \\
\left(22^{\circ} \mathrm{C}, 4 \mathrm{~h}\right)\end{array}$ & 48 & $184 \pm 39(100 \%)$ & 47 & $27 \pm 4(100 \%)$ \\
\hline $\begin{array}{l}\text { Hsp::gai-1 x GL2pro::GUS } \\
\left(37^{\circ} \mathrm{C}, 4 \mathrm{~h}\right)\end{array}$ & 38 & $158 \pm 52(86 \%)$ & 33 & $31 \pm 4(115 \%)$ \\
\hline $\begin{array}{l}\text { Hsp::gai-1 x GL2pro::GUS } \\
\left(22^{\circ} \mathrm{C}\right) 48 \mathrm{~h}^{*}\end{array}$ & 23 & $195 \pm 43(100 \%)$ & 34 & $29 \pm 3(100 \%)$ \\
\hline $\begin{array}{l}\text { Hsp::gai-1 x GL2pro::GUS } \\
\left(37^{\circ} \mathrm{C}\right) 48 \mathrm{~h}^{*}\end{array}$ & 36 & $61 \pm 19(31 \%)$ & 44 & $46 \pm 9(159 \%)$ \\
\hline pGAI::gai-1:GR (MS) & 20 & $180 \pm 56(100 \%)$ & 20 & $34 \pm 4(100 \%)$ \\
\hline pGAI::gai-1:GR (10 $\mu \mathrm{M}$ DEXA) & 29 & $129 \pm 31(72 \%)$ & 29 & $46 \pm 5(135 \%)$ \\
\hline SCR::gai-1:GR (MS) & 77 & $140 \pm 51(100 \%)$ & 77 & $34 \pm 5(100 \%)$ \\
\hline SCR::gai-1:GR (10 $\mu \mathrm{M}$ DEXA) & 64 & $70 \pm 32(50 \%)$ & 63 & $53 \pm 10(156 \%)$ \\
\hline UAS::gai-1 x C24 (control) & 46 & $154 \pm 49(100 \%)$ & 52 & $28 \pm 4(100 \%)$ \\
\hline UAS::gai-1 x J0951 (epidermis) & 54 & $155 \pm 42(101 \%)$ & 72 & $31 \pm 4(111 \%)$ \\
\hline UAS::gai-1 x J2812 (epi + cortex) & 79 & $116 \pm 48(75 \%)$ & 91 & $35 \pm 6(125 \%)$ \\
\hline
\end{tabular}


SUPRA-PHYSIOLOGICAL LEVELS OF GIBBERELLINS / DELLAS MODIFY ROOT CELL SIZE...

\begin{tabular}{lcccc}
\hline $\begin{array}{l}\text { UAS::gai-1 } \boldsymbol{x} \text { J0571 } \\
\text { (cortex + endo) }\end{array}$ & 74 & $71 \pm 18(46 \%)$ & 74 & $48 \pm 8(171 \%)$ \\
\hline $\begin{array}{l}\text { UAS::gai-1 } \boldsymbol{x} \text { M0018 } \\
\text { (cortex + endo) }\end{array}$ & 49 & $89 \pm 31(58 \%)$ & 46 & $46 \pm 9(164 \%)$ \\
\hline $\begin{array}{l}\text { UAS::gai-1 } \boldsymbol{x} \text { Q2500 } \\
\text { (MZ endo/pericycle) }\end{array}$ & 79 & $51 \pm 13(33 \%)$ & 85 & $41 \pm 8(146 \%)$ \\
\hline UAS::gai-1 $\boldsymbol{x}$ Q2393 (all but endo) & 23 & $174 \pm 59(113 \%)$ & 32 & $32 \pm 5(114 \%)$ \\
\hline $\begin{array}{l}\text { UAS::gai-1 } \boldsymbol{x} \text { J0631 } \\
\text { (elong. tissues) }\end{array}$ & 73 & $46 \pm 8(30 \%)$ & 67 & $37 \pm 6(132 \%)$ \\
\hline UAS::gai-1 $\boldsymbol{x}$ J0121 (EZ pericycle) & 16 & $177 \pm 45(115 \%)$ & 19 & $27 \pm 3(96 \%)$ \\
\hline
\end{tabular}

Table 2. Cortical and endodermal cell area in cross sections of root tips of 5-day-old A. thaliana seedlings grown under (or harbouring) excessive levels of GAs/DELLAs. Measurements of transversal cell length and width were performed on micrographs of cross sections of resin-embedded roots (40X). Area was calculated by multiplying cell length $(\mu \mathrm{m})$ by cell width $(\mu \mathrm{m})$.

\begin{tabular}{lcccc}
\hline & $\begin{array}{c}\mathbf{N}^{\mathbf{0}} \text { cross } \\
\text { sections } \\
\text { analysed }\end{array}$ & $\begin{array}{c}\text { Cortical } \\
\text { cell area }\left(\boldsymbol{\mu \mathbf { m } ^ { 2 }}\right)\end{array}$ & $\begin{array}{c}\mathbf{N}^{\mathbf{0}} \text { cross } \\
\text { sections } \\
\text { analysed }\end{array}$ & $\begin{array}{c}\text { Endodermal } \\
\text { cell area }\left(\boldsymbol{\mu m ^ { 2 }}\right)\end{array}$ \\
\hline Col (0) (MS) & 84 & $507 \pm 7(100 \%)$ & 82 & $169 \pm 3(100 \%)$ \\
\hline PAC $(\mathbf{0 . 5} \boldsymbol{\mu M})$ & 105 & $737 \pm 17(145 \%)$ & 82 & $215 \pm 7(127 \%)$ \\
\hline GA4 $(\mathbf{1} \boldsymbol{\mu M})$ & 98 & $375 \pm 13(74 \%)$ & 81 & $157 \pm 5(93 \%)$ \\
\hline Ler & 8 & $509 \pm 9(100 \%)$ & 24 & $172 \pm 4(100 \%)$ \\
\hline gai-1 & 100 & $464 \pm 5(91 \%)$ & 89 & $186 \pm 4(108 \%)$ \\
\hline QD & 16 & $264 \pm 6(52 \%)$ & 23 & $138 \pm 4(80 \%)$ \\
\hline $\mathbf{5 X}$ & 7 & $270 \pm 2(53 \%)$ & 51 & $143 \pm 3(83 \%)$ \\
\hline
\end{tabular}

Table 3. Average width of the root MZ in root tips of 5-day-old A. thaliana seedlings grown under (or harbouring) excessive levels of GAs/DELLAs. Measurements of root width were performed on micrographs of whole root tips (10X, longitudinal view) or cross sections of resin-embedded roots (40X).

\section{Root width $(\mu \mathrm{m})$}

\begin{tabular}{lcccc}
\hline & $\begin{array}{c}\mathbf{N}^{\mathbf{0}} \text { roots } \\
\text { analysed }\end{array}$ & Whole root tips & $\begin{array}{c}\mathbf{N}^{\mathbf{0}} \text { cross } \\
\text { sections } \\
\text { analysed }\end{array}$ & $\begin{array}{c}\text { Root cross } \\
\text { sections }\end{array}$ \\
\hline Col $(\mathbf{0})(\mathbf{M S})$ & 12 & $115 \pm 4(100 \%)$ & 84 & $144 \pm 10(100 \%)$ \\
\hline PAC $(\mathbf{0 . 5} \boldsymbol{\mu M})$ & 19 & $161 \pm 12(140 \%)$ & 107 & $164 \pm 14(114 \%)$ \\
\hline GA4 $(\mathbf{1} \boldsymbol{\mu M})$ & 19 & $99 \pm 12(86 \%)$ & 96 & $128 \pm 18(89 \%)$ \\
\hline Ler & 10 & $122 \pm 5(100 \%)$ & 8 & $145 \pm 4(100 \%)$ \\
\hline gai-1 & 18 & $125 \pm 18(102 \%)$ & 100 & $148 \pm 13(102 \%)$ \\
\hline QD & 16 & $107 \pm 18(88 \%)$ & 41 & $129 \pm 7(89 \%)$ \\
\hline $\mathbf{5 X}$ & 5 & $111 \pm 0(91 \%)$ & 50 & $132 \pm 8(91 \%)$ \\
\hline
\end{tabular}


Iva MCCARTHY-SUÁREZ

Table 4. Estimated tissue depth in roots tips of 5-day-old A. thaliana seedlings grown under (or harbouring) excessive levels of GAs/DELLAs. Measurements of tissue diameter $(\mu \mathrm{m})$ were performed on micrographs of cross sections of resin-embedded roots (MZ to early EZ; 40X). Estimated epidermal depth $=[$ Root diameter $($ data from table 3$)-($ Cortex-Endodermis-Pericycle-Vessels diameter $)] / 2$. Estimated cortical depth $=[($ Cortex-Endodermis-Pericycle-Vessels diameter $)-($ Endodermis-Pericycle-Vessels diameter $)] / 2$. Estimated endodermal depth $=[($ Endodermis-Pericycle-Vessels diameter $)-($ PericycleVessels diameter $)] / 2$. Estimated pericycle depth $=[$ (Pericycle-Vessels diameter $)-($ Vessels diameter $)] / 2$. Endo: Endodermis; Peri: Pericycle. Number of cross sections analysed: Control (27-29), PAC (46-49), $\mathrm{GA}_{4}$ (74-78), Ler (21-22), gai-1 (36), $Q D$ (34-36), 5X (47-48).

\begin{tabular}{|c|c|c|c|c|c|c|c|}
\hline & $\begin{array}{c}\text { Col (0) } \\
\text { (MS) }\end{array}$ & $\begin{array}{c}\text { PAC } \\
(0.5 \mu \mathrm{M})\end{array}$ & $\begin{array}{c}\mathbf{G A}_{4} \\
(1 \mu \mathrm{M})\end{array}$ & Ler & gai-1 & $Q D$ & $5 X$ \\
\hline $\begin{array}{l}\text { Cortex-Endo- } \\
\text { Peri-Vessels } \\
\text { diameter }\end{array}$ & $\begin{array}{c}95 \pm 6 \\
(100 \%)\end{array}$ & $\begin{array}{l}110 \pm 11 \\
(116 \%)\end{array}$ & $\begin{array}{l}83 \pm 12 \\
(87 \%)\end{array}$ & $\begin{array}{c}90 \pm 7 \\
(100 \%)\end{array}$ & $\begin{array}{c}91 \pm 5 \\
(101 \%)\end{array}$ & $\begin{array}{l}81 \pm 5 \\
(90 \%)\end{array}$ & $\begin{array}{l}82 \pm 4 \\
(91 \%)\end{array}$ \\
\hline $\begin{array}{l}\text { Endo-Peri- } \\
\text { Vessels } \\
\text { diameter }\end{array}$ & $\begin{array}{c}59 \pm 6 \\
(100 \%)\end{array}$ & $\begin{array}{c}70 \pm 7 \\
(119 \%)\end{array}$ & $\begin{array}{l}58 \pm 7 \\
(98 \%)\end{array}$ & $\begin{array}{c}60 \pm 4 \\
(100 \%)\end{array}$ & $\begin{array}{l}59 \pm 3 \\
(98 \%)\end{array}$ & $\begin{array}{l}59 \pm 6 \\
(98 \%)\end{array}$ & $\begin{array}{l}55 \pm 2 \\
(92 \%)\end{array}$ \\
\hline $\begin{array}{l}\text { Peri-Vessels } \\
\text { diameter }\end{array}$ & $\begin{array}{c}45 \pm 5 \\
(100 \%)\end{array}$ & $\begin{array}{c}54 \pm 5 \\
(120 \%)\end{array}$ & $\begin{array}{c}45 \pm 6 \\
(100 \%)\end{array}$ & $\begin{array}{c}45 \pm 3 \\
(100 \%) \\
\end{array}$ & $\begin{array}{l}44 \pm 2 \\
(98 \%)\end{array}$ & $\begin{array}{c}45 \pm 5 \\
(100 \%)\end{array}$ & $\begin{array}{l}40 \pm 2 \\
(89 \%)\end{array}$ \\
\hline $\begin{array}{l}\text { Vessels } \\
\text { diameter }\end{array}$ & $\begin{array}{c}35 \pm 3 \\
(100 \%)\end{array}$ & $\begin{array}{c}40 \pm 3 \\
(114 \%)\end{array}$ & $\begin{array}{l}32 \pm 5 \\
(91 \%)\end{array}$ & $\begin{array}{c}33 \pm 3 \\
(100 \%)\end{array}$ & $\begin{array}{c}34 \pm 2 \\
(103 \%)\end{array}$ & $\begin{array}{c}33 \pm 4 \\
(100 \%)\end{array}$ & $\begin{array}{l}30 \pm 2 \\
(91 \%)\end{array}$ \\
\hline $\begin{array}{l}\text { Estimated } \\
\text { Epidermal } \\
\text { depth }\end{array}$ & $\begin{array}{c}25 \\
(100 \%)\end{array}$ & $\begin{array}{c}27 \\
(108 \%)\end{array}$ & $\begin{array}{c}22 \\
(88 \%)\end{array}$ & $\begin{array}{c}27 \\
(100 \%)\end{array}$ & $\begin{array}{c}28 \\
(104 \%)\end{array}$ & $\begin{array}{c}24 \\
(89 \%)\end{array}$ & $\begin{array}{c}25 \\
(93 \%)\end{array}$ \\
\hline $\begin{array}{l}\text { Estimated } \\
\text { Cortex depth }\end{array}$ & $\begin{array}{c}18 \\
(100 \%)\end{array}$ & $\begin{array}{c}20 \\
(111 \%)\end{array}$ & $\begin{array}{c}13 \\
(72 \%)\end{array}$ & $\begin{array}{c}15 \\
(100 \%)\end{array}$ & $\begin{array}{c}16 \\
(107 \%)\end{array}$ & $\begin{array}{c}11 \\
(73 \%)\end{array}$ & $\begin{array}{c}13 \\
(87 \%)\end{array}$ \\
\hline $\begin{array}{l}\text { Estimated } \\
\text { Endodermis } \\
\text { depth }\end{array}$ & $\begin{array}{c}7 \\
(100 \%)\end{array}$ & $\begin{array}{c}8 \\
(114 \%)\end{array}$ & $\begin{array}{c}6 \\
(86 \%)\end{array}$ & $\begin{array}{c}8 \\
(100 \%)\end{array}$ & $\begin{array}{c}7 \\
(88 \%)\end{array}$ & $\begin{array}{c}7 \\
(88 \%)\end{array}$ & $\begin{array}{c}7 \\
(88 \%)\end{array}$ \\
\hline $\begin{array}{l}\text { Estimated } \\
\text { Pericycle depth }\end{array}$ & $\begin{array}{c}5 \\
(100 \%) \\
\end{array}$ & $\begin{array}{c}7 \\
(140 \%) \\
\end{array}$ & $\begin{array}{c}6 \\
(120 \%) \\
\end{array}$ & $\begin{array}{c}6 \\
(100 \%) \\
\end{array}$ & $\begin{array}{c}5 \\
(83 \%) \\
\end{array}$ & $\begin{array}{c}6 \\
(100 \%) \\
\end{array}$ & $\begin{array}{c}5 \\
(83 \%) \\
\end{array}$ \\
\hline
\end{tabular}

Table 5. Radial cell organization in roots of 5 or 7-day-old A. thaliana seedlings grown under (or harbouring) excessive levels of GAs/DELLA. Analyses performed on micrographs of cross sections of resin embedded-roots (40X).

\begin{tabular}{lccccc}
\hline & $\begin{array}{c}\mathbf{N}^{\mathbf{o}} \text { root cross sections } \\
\text { analysed }\end{array}$ & Epidermis & Cortex & Endodermis & Pericycle \\
\hline Control (5d) & 75 & $20-25$ & 8 & $8-10$ & $13-15$ \\
\hline PAC (5d) & 56 & $25-34$ & $8-9$ & $9-13$ & $14-18$ \\
\hline GA4 (5d) & 56 & $17-25$ & $8-9$ & $8-10$ & $12-16$ \\
\hline Control (7d) & 14 & $24-27$ & 8 & $8-10$ & $14-15$ \\
\hline PAC (7d) & 18 & $26-33$ & $8-10$ & $11-13$ & $14-18$ \\
\hline GA4 (7d) & 45 & $23-25$ & $8-9$ & $8-10$ & $14-16$ \\
\hline Ler (5d) & 13 & $18-24$ & 8 & 8 & $13-14$ \\
\hline gai-1 (5d) & 57 & $19-25$ & 8 & $8-9$ & $12-14$ \\
\hline QD (5d) & 24 & $22-24$ & $8-11$ & $8-11$ & $14-18$ \\
\hline 5X (5d) & 54 & $18-21$ & $8-9$ & $7-8$ & $12-16$
\end{tabular}


SUPRA-PHYSIOLOGICAL LEVELS OF GIBBERELLINS / DELLAS MODIFY ROOT CELL SIZE...

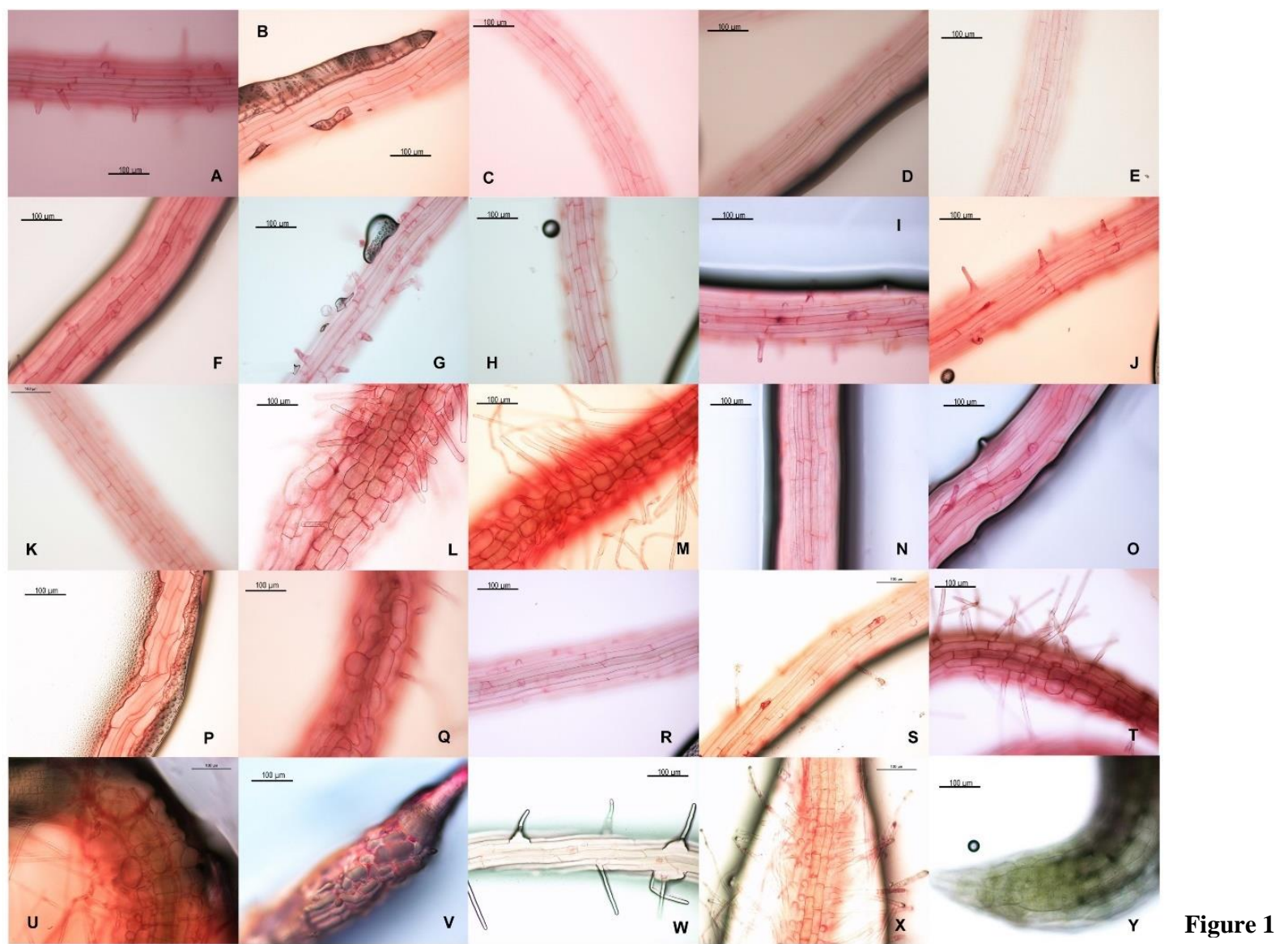




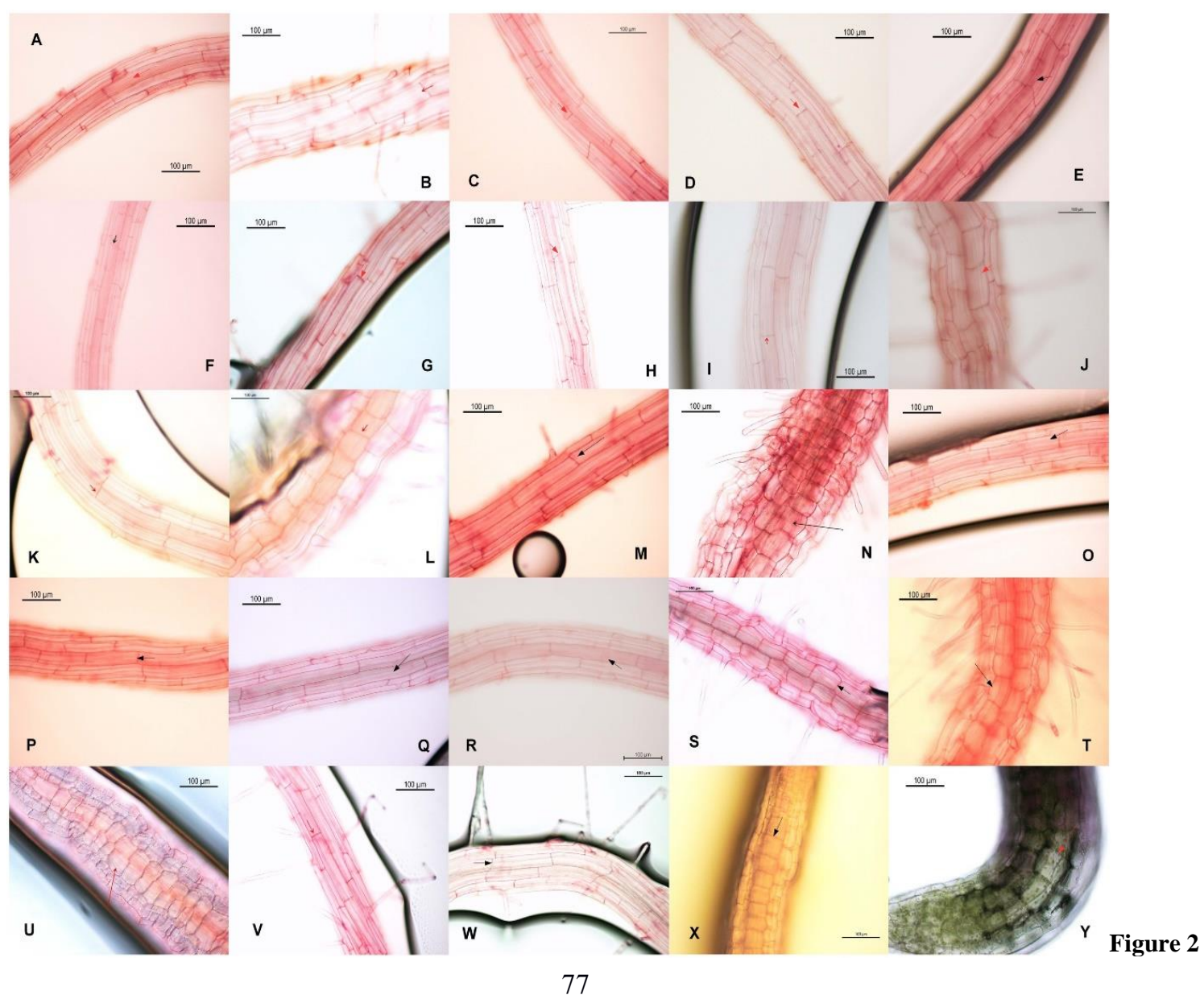


SUPRA-PHYSIOLOGICAL LEVELS OF GIBBERELLINS / DELLAS MODIFY ROOT CELL SIZE...

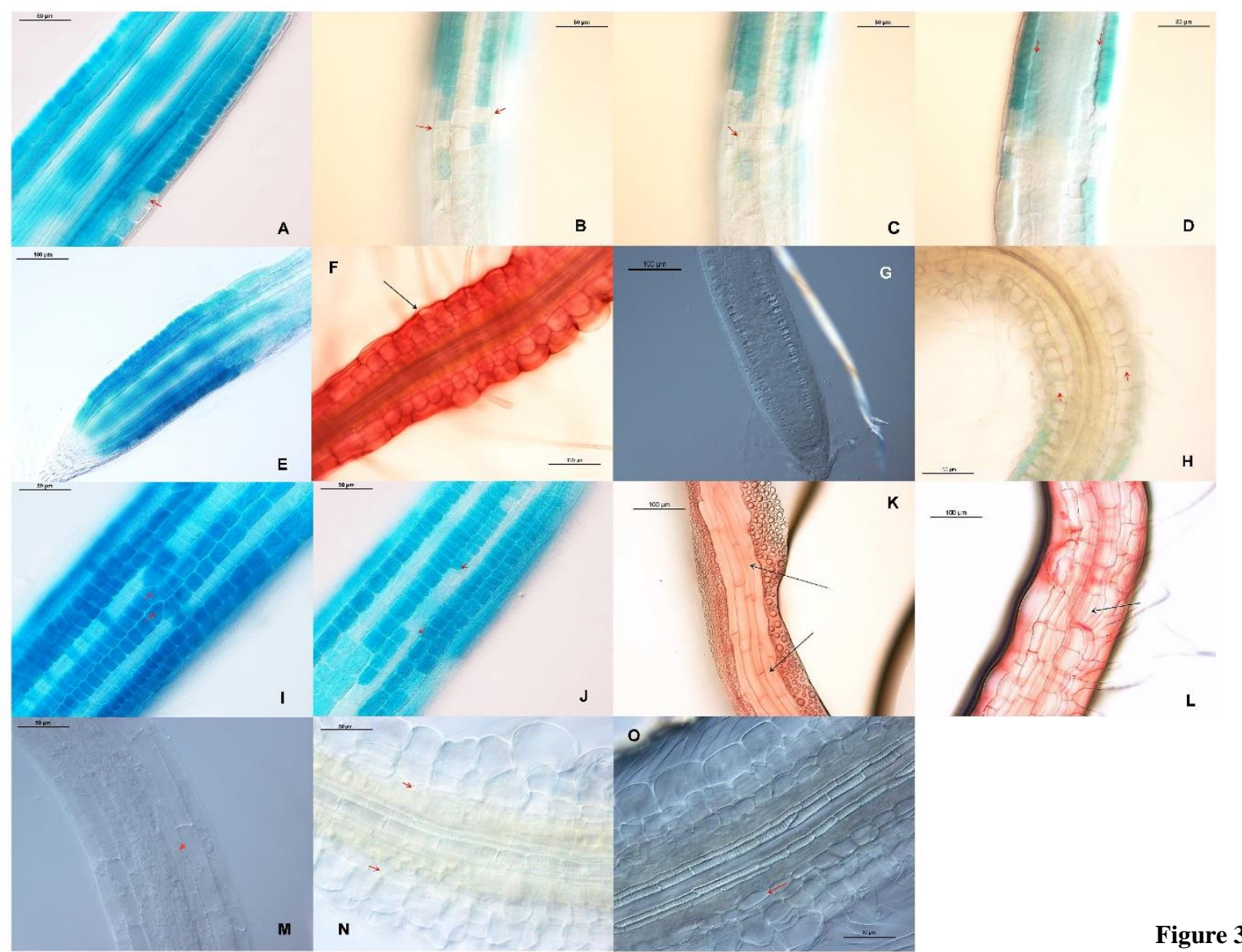


Iva MCCARTHY-SUÁREZ

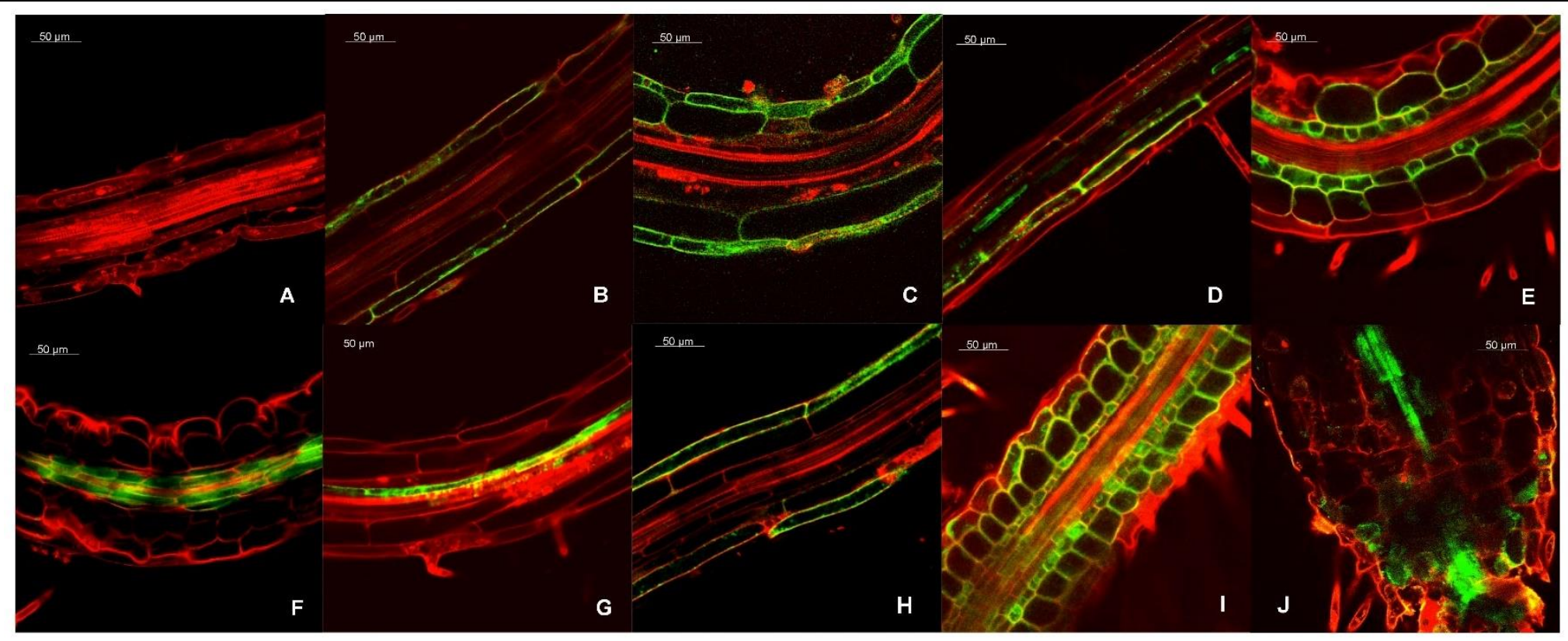

Figure 4 
SUPRA-PHYSIOLOGICAL LEVELS OF GIBBERELLINS / DELLAS MODIFY ROOT CELL SIZE...

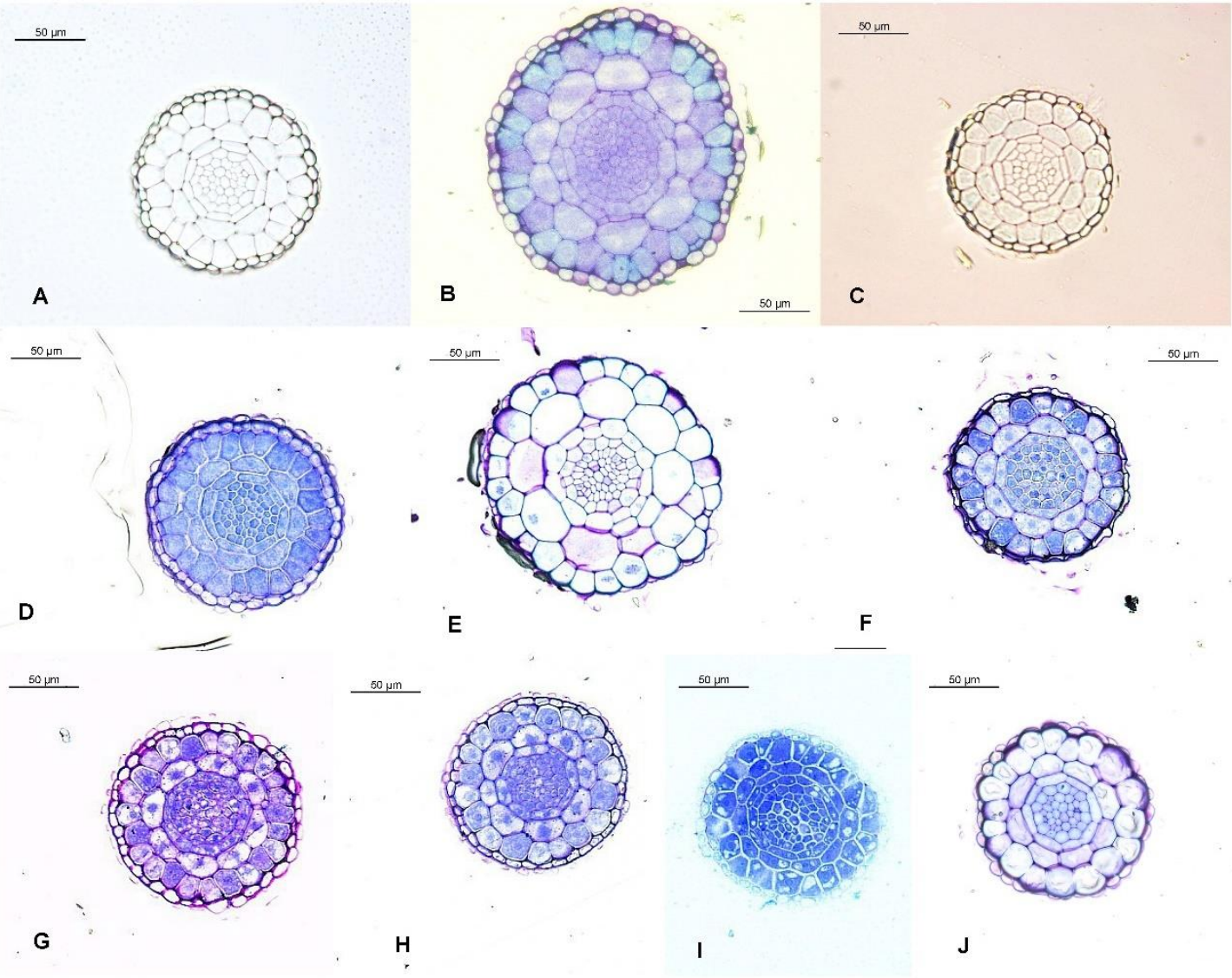




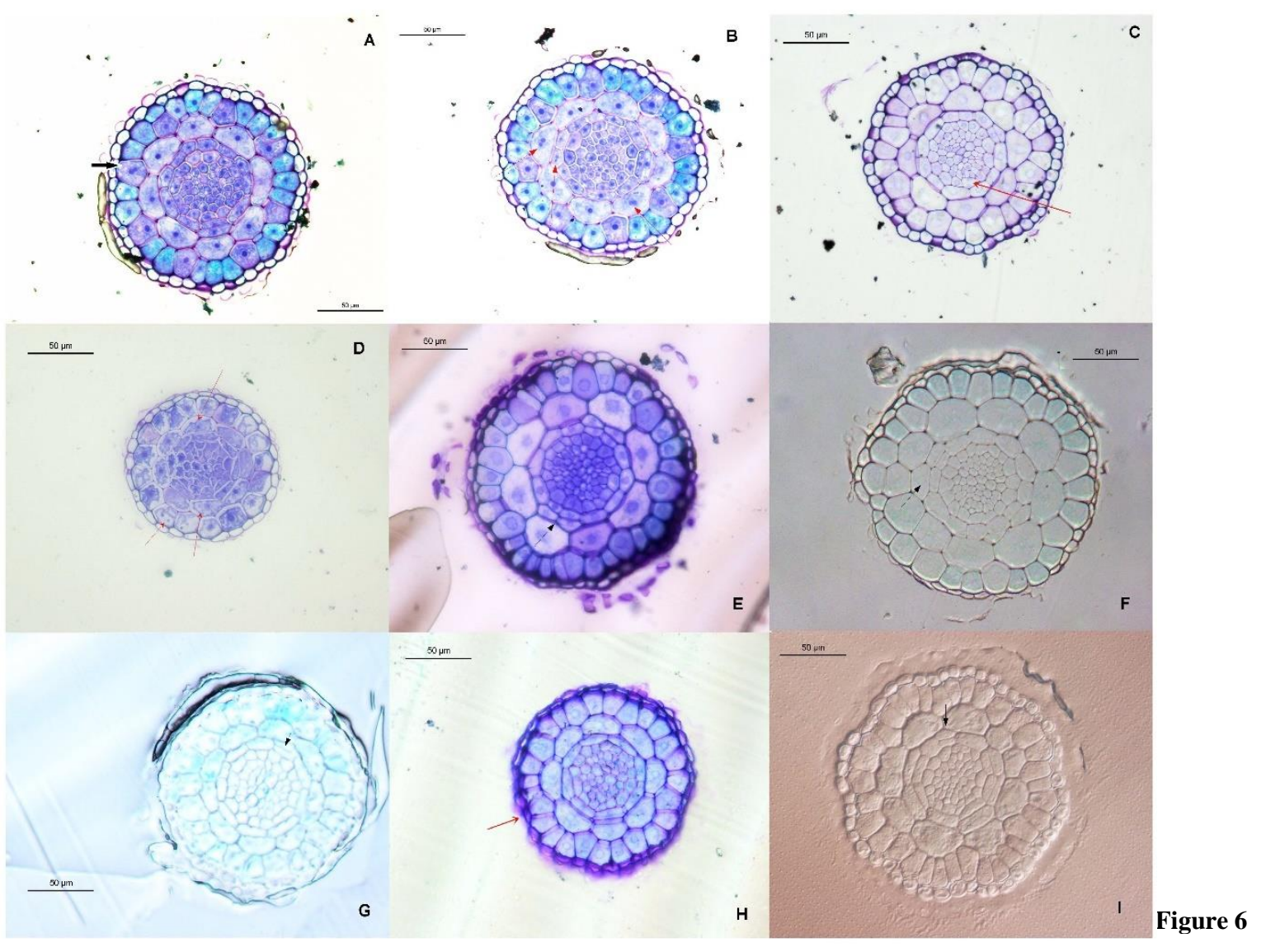


SUPRA-PHYSIOLOGICAL LEVELS OF GIBBERELLINS / DELLAS MODIFY ROOT CELL SIZE...

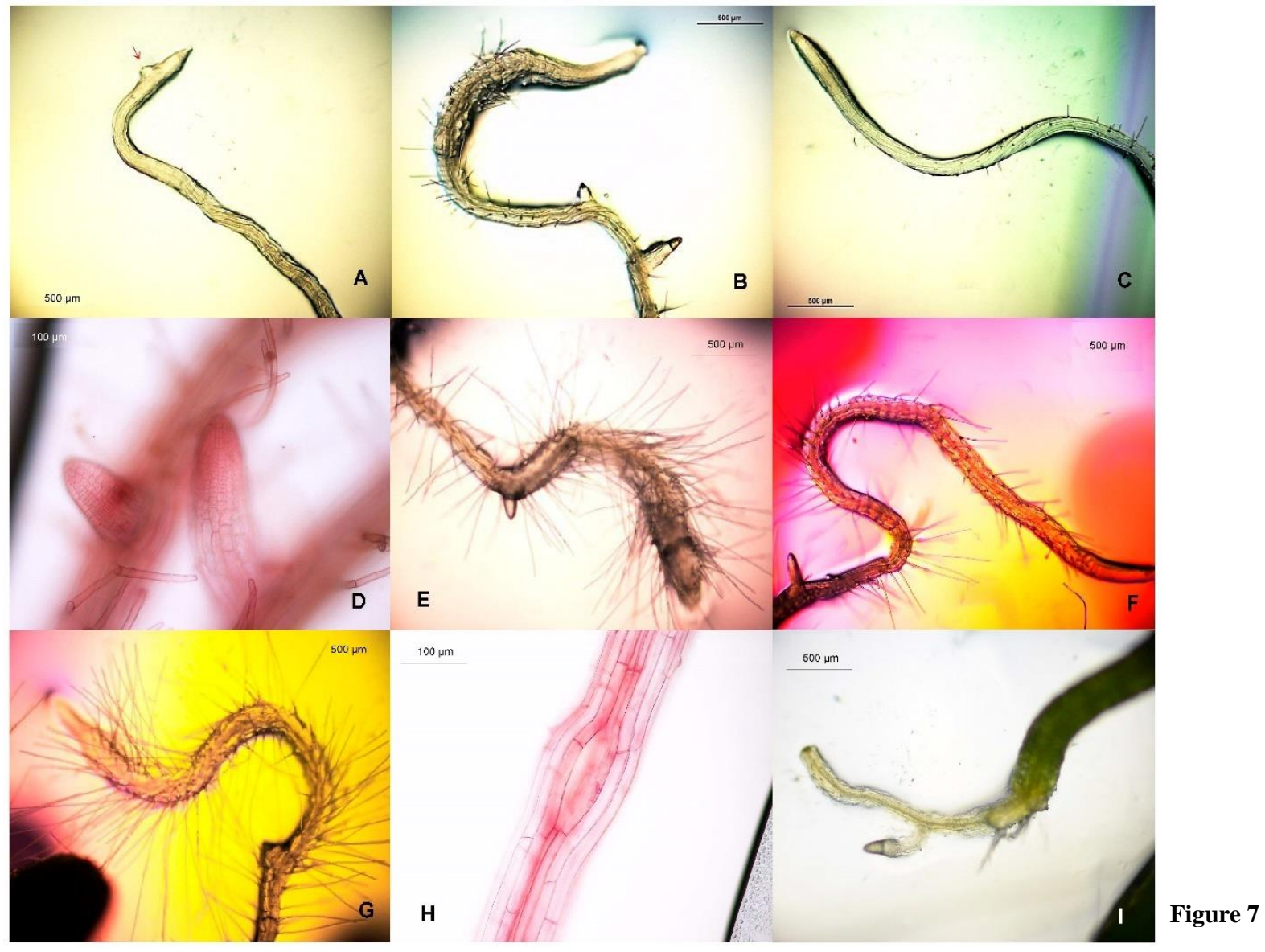




\section{Figure legends}

Figure 1. Excessive levels of GAs/DELLAs altered the size of root epidermal cells in root tips of 5-dayold A. thaliana seedlings. A) $\operatorname{Col}(0)(\mathrm{MS})$; B) $\mathrm{Col}(0)(0.5 \mu \mathrm{M}$ PAC); C) $\operatorname{Col}(0)(30 \mu \mathrm{M} \mathrm{GA3})$; D) Col (0) $(1 \mu \mathrm{M} \mathrm{GA} 4)$; E) Ler; F) gai-1; G) $Q D$; H) $5 X$; I) GID1b-ox (MS); J) HSp ::gai-1 $\left(22^{\circ} \mathrm{C}, 4\right.$ h); K) HSp ::gai1 (immediately after heat shock $\left.\left(37^{\circ} \mathrm{C}, 4 \mathrm{~h}\right) ; \mathbf{L}\right) H S p::$ gai-1 $\left(24 \mathrm{~h}\right.$ after heat-shock $\left.\left(37{ }^{\circ} \mathrm{C}, 4 \mathrm{~h}\right) ; \mathbf{M}\right)$ HSp::gai-1 (48 h after heat-shock $\left(37^{\circ} \mathrm{C}, 4 \mathrm{~h}\right)$; N) pGAI::gai-1:GR (MS); O) pGAI::gai-1:GR (10 $\mu \mathrm{M}$ DEXA); P) SCR::gai-1:GR (MS, leaky line); Q) SCR::gai-1:GR (10 $\mu \mathrm{M}$ DEXA); R) UAS::gai-1 x C24; S) UAS::gai-1 x J0951; T) UAS::gai-1 x J2812; U) UAS::gai-1 x J0571; V) UAS::gai-1 x Q2500; W) UAS::gai-1 x J0121; X) UAS::gai-1 x J0631; Y) UAS::gai-1 x J3281. Magnification: 20X. The scale bar represents $100 \mu \mathrm{m}$. Propidium iodide staining.

Figure 2. Excessive levels of GAs/DELLAs altered the size of root cortical cells in root tips of 5-day-old A. thaliana seedlings. A) $\mathrm{Col}(0)(\mathrm{MS})$; B) $\mathrm{Col}(0)(0.5 \mu \mathrm{M}$ PAC); C) $\mathrm{Col}(0)(1 \mu \mathrm{M} \mathrm{GA} 4)$; D) Ler; E) gai1 ; F) $Q D$; G) $5 X$; H) GID $1 b$-ox; I) pGAI::gai-1:GR (3d in MS); J) pGAI::gai-1:GR (3d in $10 \mu \mathrm{M}$ DEXA); K) SCR::gai-1:GR (3d in MS); L) SCR::gai-1:GR (3d in $10 \mu \mathrm{M}$ DEXA); M) HSp::gai-1 x GL2pro::GUS (24h after $22{ }^{\circ} \mathrm{C}$ for $4 \mathrm{~h}$ ); N) HSp::gai-1 x GL2pro::GUS (24h after heat-shock $\left(37^{\circ} \mathrm{C}\right.$ for $\left.4 \mathrm{~h}\right)$ ); O) GL2pro::GUS (heat-shock control) (24 h after $22^{\circ} \mathrm{C}$ for $4 \mathrm{~h}$ ); P) GL2pro::GUS (heat-shock control) (24h after heat shock $\left(37^{\circ} \mathrm{C}\right.$ for $\left.4 \mathrm{~h}\right)$ ); Q) UAS::gai-1 x C24; R) ML1::gai-1; S) UAS::gai-1 x J2812; T) UAS::gai-1 x M0018; U) UAS::gai-1 x Q2500; V) UAS::gai-1 x N9142; W) UAS::gai-1 x J0121; X) UAS::gai-1 x 0631; Y) UAS::gai-1 x J3281. Magnification: 20X. The scale bar represents $100 \mu \mathrm{m}$. Propidium iodide staining.

Figure 3. Excessive levels of GAs/DELLAs induced cell size changes and T-clones at the epidermis, cortex and endodermis of root tips of 5-day-old A. thaliana seedlings. A) GL2pro:: GUS (30 $\mu \mathrm{M} \mathrm{GA} 3$ ) (all layers): expansion of an epidermal cell and narrowing of a cortical cell coincide with a change in epidermal cell fate, 40X; B) $35 S: \because C P C$ x GL2pro::GUS (epidermis): A change in epidermal cell size coincides with a change in epidermal cell fate, 40X; C) $35 S: \because C P C \times$ GL2pro::GUS (cortex): A change in the width of a cortical cell coincides with a change in epidermal cell fate, 40X; D) $35 S:: C P C$ x GL2pro::GUS (all layers): epidermis and cortex vary in cell size, 40X; E) HSp::gai-1 x GL2pro::GUS (48 h after $22^{\circ} \mathrm{C}$ for $4 \mathrm{~h}$ ) (all layers), 20X; F) HSp::gai-1 x GL2pro::GUS (48h after heat-shock $\left(37^{\circ} \mathrm{C}, 4 \mathrm{~h}\right.$ ) (all layers): swelling of the root epidermal, cortical, endodermal and pericyclic cells, 20X; G) SCR::gai- 1:GR (MS) (all layers), 20X; H) SCR::gai-1:GR x GL2pro::GUS (24 h in $10 \mu \mathrm{M}$ DEXA) (all layers): swelling of the root cortex, endodermis and pericycle, 20X; I) Epidermal T-clones in PAC $(0.5 \mu \mathrm{M}), 40 \mathrm{X}$; J) Epidermal T-clones in GA3 $(30 \mu \mathrm{M}), 40 \mathrm{X}$; K) SCR::gai-1:GR (0.2 $\mu \mathrm{M}$ DEXA): epidermal T-clones, 20X; L) SCR::gai-1:GR (1.2 $\mu$ M DEXA): periclinal cell division at the root cortex, 20X; M) SCR::gai-1:GR (MS) (all layers): arrow on endodermis, 40X; N) SCR::gai-1:GR (10 $\mu \mathrm{M}$ DEXA) (all layers): periclinal cell divisions at the endodermis, 40X; O) SCR::gai-1:GR (10 $\mu \mathrm{M}$ DEXA) (all layers): periclinal cell divisions at the endodermis, 40X. The scale bar represents $100 \mu \mathrm{m}(20 \mathrm{X})$ or $50 \mu \mathrm{m}(40 \mathrm{X})$. Propidium iodide or GUS staining.

Figure 4. Over-expression of gai-1 in different tissues of the root modified the cell size in root tips of 5day-old A. thaliana seedlings. A) UAS::gai-1 x C24 (Background); B) UAS::gai-1 x J0951 (epidermis of the MZ); C) UAS::gai-1 x J2812 (epidermis and cortex of the MZ); D) UAS::gai-1 x N9142 (cortex of EZ); E) UAS::gai-1 x J0571 (cortex and endodermis of the MZ); F) UAS::gai-1 $\mathrm{x}$ Q2500 (endodermis/pericycle of MZ); G) UAS::gai-1 x J0121 (pericycle of EZ); H) UAS::gai-1 x Q2393 (all tissues but the endodermis); I) UAS::gai-1 x J0631 (elongating tissues); J) UAS::gai-1 x J3281 (vessels). Magnification: 40X. The scale bar represents $50 \mu \mathrm{m}$. Propidium iodide staining. 
Figure 5. Radial cell organization in root tips of 5 or 7 day-old $A$. thaliana seedlings grown under (or harbouring) excessive levels of GAs/DELLAs. A) $\operatorname{Col}(0)(\mathrm{MS}, 5 \mathrm{~d})$; B) $\mathrm{Col}(0)(0.5 \mu \mathrm{M} \mathrm{PAC}, 5 \mathrm{~d})$; C) $\mathrm{Col}(0)$ (1 $\mu \mathrm{M} \mathrm{GA} 4,5 \mathrm{~d})$; D) $\operatorname{Col}(0)(\mathrm{MS}, 7 \mathrm{~d})$; E) $\operatorname{Col}(0)(0.5 \mu \mathrm{M}$ PAC, 7d); F) $\operatorname{Col}(0)(1 \mu \mathrm{M} \mathrm{GA} 4,7 \mathrm{~d})$; G) Ler (5d); H) gai-1 (5d); I) $Q D(5 \mathrm{~d})$; J) $5 X$ (5d). Magnification: 40X. The scale bar represents $50 \mu \mathrm{m}$. Toluidine blue staining.

Figure 6. Excessive levels of GAs/DELLAs induced multinucleated cells, a middle cortex (MC) and extra cortical cells in root tips of $A$. thaliana seedlings. A) PAC $(0.5 \mu \mathrm{M}, 5 \mathrm{~d})$ : Epidermal multinucleated cell; B) PAC $(0.5 \mu \mathrm{M}, 5 \mathrm{~d})$ : Cortical and endodermal multinucleated cells; C) PAC $(0.5 \mu \mathrm{M}, 5 \mathrm{~d})$ : Pericyclic multinucleated cell; D) GA4 (1 $\mu \mathrm{M}, 5 \mathrm{~d})$ : Epidermal and cortical multinucleated cells; E) PAC $(0.5 \mu \mathrm{M}$, 5d): MC; F) PAC ( $0.5 \mu \mathrm{M}, 7 \mathrm{~d})$ : MC (arrow) and 10 cortical cells; G) GA4 (1 $\mu \mathrm{M}, 5 \mathrm{~d})$ : MC (arrow) and 9 cortical cells; H) scm x GL2pro::GUS (MS, 5d); I) scm x GL2pro::GUS (0.5 $\mu \mathrm{M}$ PAC, 5d): MC (arrow) and 9 cortical cells. Magnification: 40X. The scale bar represents $50 \mu \mathrm{m}$. Toluidine blue staining.

Figure 7. Over-expression of gai-1 induced an early outburst of lateral roots in root tips of $A$. thaliana seedlings. A) SCR::gai-1:GR (MS, 5d) (Leaky line), 4X; B) SCR::gai-1:GR (10 $\mu \mathrm{M}$ DEXA, 5d), 4X; C) UAS::gai-1 x C24 (control, 5d), 4X; D) UAS::gai-1 x J2812 (5d), 20X; E) UAS::gai-1 x M0018 (5d), 4X; F) UAS::gai-1 x J0571 (5d), 4X; G) UAS::gai-1 x Q2500 (5d), 4X; H) UAS::gai-1 x N9142 (5d), 20X; I) UAS::gai-1 x J3281 (8d) (aborted primary root), 4X. The scale bar represents $100 \mu \mathrm{m}(20 \mathrm{X})$ or $500 \mu \mathrm{m}(4 \mathrm{X})$.

\section{Discussion}

\section{The GAs/DELLAs might regulate the size and number of root tip cells in seedlings of A. thaliana.}

\section{Root cell size: Connections to the root hair patterning and abundance}

Apart from altering the patterning, morphology and abundance of root hairs [MCCARTHY-SUÁREZ, unpublished manuscript], results of the present study suggest that excessive levels of GAs/DELLAs also modified the size of root tip cells in seedlings of $A$. thaliana. While excessive levels of DELLAs frequently shortened and widened the epidermal, cortical, endodermal and pericyclic cells of the root, what resulted in wider root tips, excessive levels of GAs, with the exception of the epidermal cells, often narrowed them. Thus, because root hair cells are shorter than the root non-hair cells [SALAZAR-HENAO \& al. 2016], then, the inhibition of epidermal cell elongation that occurred when gai-1 was over-expressed in tissues placed underneath the MZ epidermis (J2812 > gai-1, J0571 >> gai-1, M0018 > gai-

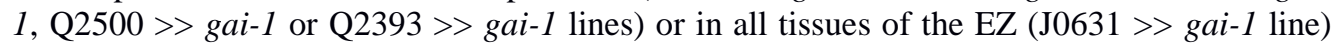
might have contributed, in part, to the appearance of ectopic root hairs, and, therefore, to the higher density of root hairs observed near the root tip under excessive levels of DELLAs [MCCARTHY-SUÁREZ, unpublished manuscript]. In fact, Arabidopsis increases root hair density by decreasing the length of root epidermal cells, as shown under P deficiency [JIANG \& al. 2007; PÉRET \& al. 2011; SALAZAR-HENAO \& al. 2016; JANES \& al. 2018]. Alternatively, given that GAs promote the elongation of root epidermal cells, accumulate at the endodermis of the root EZ, and affect the expansion of root EZ cells by destabilizing DELLAs and inducing expansin genes [UBEDA-TOMÁS \& al. 2008, 2009; GOU \& al. 2010; BAHIN \& al. 2011; SHANI \& al. 2013], then, the extra elongation of root epidermal cells which is known to occur under high levels of GAs [BAND \& al. 2012] might have contributed, in turn, to the lower density of root hairs that was observed at the root tip under this treatment [MCCARTHY- 
SUÁREZ, unpublished manuscript]. In fact, in WT, cell expansion at the root EZ is strictly polar and is not accompanied by an increase in the root diameter [BAO \& al. 2001].

Interestingly, epidermal patterning genes instruct epidermal cell size [LÖFKE \& al. 2013]. In turn, variations in the expression of HDA 19 (histone deacetylase 19), which controls epidermal cell elongation, affect root cell elongation and, thus, root hair density [CHEN \& al. 2015; SALAZAR-HENAO \& al. 2016]. In this study, however, neither the patterning or abundance of root hairs [MCCARTHY-SUÁREZ, unpublished manuscript] nor the epidermal cell length seemed to suffer any alterations when gai-1 was over-expressed at the root epidermis (Figure 4), what suggests that the changes of cell size induced by excessive levels of GAs/DELLAs in roots of $A$. thaliana seedlings might have been orchestrated from the subepidermal tissues of the root. Furthermore, WILD \& al. (2016) showed that expressing gai-1 at the root epidermis did not affect the root length.

Results of this study also seem to point at a link between cell size and cell fate, because expressing gai-1 at the elongating tissues of the root (J0631 > gai-1) caused the shortening and widening of the majority of the root cells (Figures 1,2 and 4) along with a hairy phenotype similar to that of the wer mutant [MCCARTHY-SUÁREZ, unpublished manuscript]. In fact, the DELLAs inhibit the elongation of root EZ cells and primary root [ALONSO-RAMÍREZ \& al. 2009; UBEDA-TOMÁS \& al. 2009; LEE \& al. 2012] and down-regulate PIF4, a phytochrome-interacting factor which induces cell elongation genes [ACHARD \& GENSCHIK, 2009]. Deficiencies in $\mathrm{B}, \mathrm{P}$ or Fe, which increase the levels of DELLAs at the root $\mathrm{MZ}$ and induce ectopic root hairs, also reduce the primary root length [MARTÍN-REJANO \& al. 2011; PÉRET \& al. 2011; WILD \& al. 2016]. Furthermore, it has been suggested that production of ectopic root hairs in ectopic root hair 2 (erh2) occurs at late stages of root development, correlated with cell expansion. However, it has also been suggested the independence of root hair initiation from cell expansion, as erh3 acts as soon as cell fate specification [SCHNEIDER $\&$ al. 1997]. Particularly, ERH3 is required for the stable fixation of positional signals at the cell wall $(\mathrm{CW})$ for cell fate specification. Moreover, ERH3 codifies a MT-severing p60 katanin protein and has a role in CW biosynthesis [WEBB \& al. 2002]. On the other hand, given that the expression of cell identity markers is altered in erh3, it has been suggested that MT are directly active in the specification of root cell identity, and that MT disruption in erh 3 results in the development of defective identities [WEBB \& al. 2002]. In fact, in several animal systems, MT are involved in the specification of cell identity and polarity [WEBB \& al. 2002].

Shortening and radial expansion of root cortical and endodermal cells has also been reported in the cobra, pom-1 (both cellulose deficient), shoebox (GA biosynthesis-impaired), $d g l l$ (GA-insensitive), TUA6/AS ( $\alpha$-tubulin-deficient), erh, sabre, PLD (phospholipase D), wer, $s c m$ and $j k d$ mutants, in plants treated with umbelliferone (a cellulose biosynthesis inhibitor), MT-breaking drugs or 1-butanol (an inhibitor of PLD), and in plants stressed by salinity, gamma irradiation or mineral deficiency (Fe, P) [JANKAY \& MULLER, 1976; SCHIEFELBEIN \& al. 1997; SCHNEIDER \& al. 1997; BAO \& al. 2001; MA \& al. 2001; SCHERES \& al. 2002; GARDINER \& al. 2003; NAGATA \& al. 2004; KOMORISONO \& al. 2005; WELCH \& al. 2007; DINNENY \& al. 2008; PIETRA \& al. 2015; JANES \& al. 2018]. Cortical cell expansion as a result of excessive DELLAs has also been described by BENFEY $\&$ al. [1993]. Interestingly, PAC induces the expression of expansin genes at the root cortex (At4g21280 (+2,002); Arex data), being EXPANSIN 7 a specific marker of root hair cells [OHASHI \& al. 2003; GENDRE \& al. 2019]. In addition, it has been suggested that the DELLA GAI might have a role in the expansion of endodermal cells in Arabidopsis primary roots, and that the expansion of endodermal cells determines the elongation of whole roots [UBEDA- 
TOMÁS \& al. 2009; ZHANG \& al. 2014). On the other hand, the GAs control the size of the root apical meristem (RAM) in Arabidopsis by affecting cortical cell expansion [NELISSEN \& al. 2012; FONOUNI-FARDE \& al. 2019]. In fact, for different accessions of Arabidopsis, there is a correlation between cortex cell length and the length of the root MZ [ZHANG \& al. 2014]. Furthermore, when gai-1 is over-expressed at the root endodermis (the most important tissue for GA-dependent root growth), the cessation of anisotropic cell growth expands radially the cortical cells and causes the outward protrusion of epidermal cells [UBEDA-TOMÁS \& al. 2008]. With this regard, it is known that the endodermis of the EZ regulates nutrient uptake [PÉRET \& al. 2011; SHANI \& al. 2013; CUI, 2015], whereas the cortex participates in the root response to $\mathrm{P}$ deficiency [SHIN \& al. 2005].

Therefore, the shortening and widening of the root epidermal, cortical, endodermal and pericycle cells induced by excessive levels of DELLAs in seedlings of $A$. thaliana might have explained the radial expansion of the root tips observed. Interestingly, treatment with PAC also increased the root diameter in carrot [WANG \& al. 2015]. In fact, in this study, root tips became thinner under excessive GAs (Table 3), as previously reported in carrot and Eucalyptus grandis [WANG \& al. 2015; LIU \& al. 2018]. A wider root diameter has also been described in the arm, sabre, cobra, erh-1, pom-poml and $\alpha$-tubulin under-expressing mutants, and in plants exposed to 1-butanol, umbelliferone, gamma irradiation or P deficiency [JANKAY \& MÜLLER, 1976; SCHNEIDER \& al. 1997; BAO \& al. 2001; MA \& al. 2001; GARDINER \& al. 2003; NAGATA $\&$ al. 2004; HERMANS \& al. 2010; PIETRA, 2014]. Moreover, the reduction of the actin cytoskeleton induces the radial expansion of plant cells, making them shorter and wider, as the interphase MT determine the direction of plant cell elongation [BALUŠKA \& al. 2001; BAO $\&$ al. 2001]. This means that the capacity of cells to elongate longitudinally depends on the orientation of the cytoskeletal MT [DUGARDEYN \& VAN DER STRAETEN, 2008]. Thus, a reduced expression of the $\alpha$-tubulin gene in $A$. thaliana seedlings results in an abnormal expansion of the root tip (MZ and EZ), with its diameter increasing dramatically at 8 days after germination [BAO \& al. 2001]. De-polymerization of MT by oryzalin or 1-butanol also causes the swelling of the root MZ and EZ in A. thaliana seedlings, whereas MT stabilization by Taxol expands the root EZ and DZ [BAO \& al. 2001; GARDINER \& al. 2003].

Therefore, a connection exists between aberrant orientation of MT and reduced cell elongation, as MT regulate the oriented deposition of cellulose microfibrils that determines the direction of cell elongation [BURK \& YE, 2002]. More specifically, MT are essential for anisotropic cell expansion because they direct the insertion of cellulose synthase in the CW and guide the orientation of cellulose microfibrils to a perpendicular position with respect to the growth axis, thereby restricting radial cell expansion [JANKAY \& MULLER, 1976; LIN \& al. 2013]. Interestingly, mutations in P60 katanin protein, essential for anisotropic cell growth, cause an inappropriate feedback regulation of the DGL1 gen for GAs biosynthesis [KOMORISONO \& al. 2005].

With this respect, a link has been proposed between aberrant orientation of MT, radial cell growth and alteration of the root hair patterning [BALUŠKA \& al. 2001; BAO \& al. 2001]. Thus, a low expression of the $\alpha$-tubulin gene (TUA6/AS transgenic lines), mutations that inhibit MT polymerization or drugs that brake the actin MT produce aberrant microtubular structures, expand radially the root tip cells, especially at the epidermis and cortex of the MZ and EZ, and induce ectopic root hairs in 5 day-old $A$. thaliana seedlings [BAO \& al. 2001; COLLINGS \& al. 2006]. On the other hand, the erhl and erh3 mutants, with an altered root hair patterning, exhibit disorganized MT and radially-enlarged layers of root cortex and endodermis, what suggests a connection between radial cell expansion and root hair initiation [SCHNEIDER \& 
al. 1997; BOUQUIN \& al. 2003; MÜLLER \& SCHMIDT, 2004; PIETRA \& al. 2015]. Moreover, erh2 is allelic to pom-1, a mutant with abnormally-expanded layers of root epidermis and cortex [SCHNEIDER \& al. 1997; PIETRA \& al. 2015]. In fact, not only cell length, but also cell width differs between Trichoblasts and Atrichoblasts [LÖFKE \& al. 2013]. Deficiencies in Fe or P also induce the swelling of root cortical cells, along with ectopic root hairs [PIETRA \& al. 2015]. Another clue about the link among MT, cell expansion and cell fate is illustrated by the mutants cobra and sabre, both with an abnormal cell expansion at the root tip and ectopic root hairs [SCHIEFELBEIN \& al. 1997]. The mutation of the SABRE protein, involved in MT organization, causes an abnormal cell expansion at the root cortex [BENFEY $\&$ al. 1993], whereas the mutation of the COBRA protein, which is associated to the longitudinal $\mathrm{CW}$ of the rapidly-growing root EZ, entails a cellulose deficiency and causes the swelling of the root epidermis and cortex [SCHERES \& al. 2002]. Interestingly, the GAs influence CW growth in mesocotyl epidermal cells [PERAZZA \& al. 1998]. Therefore, under the experimental conditions of the present study, excessive levels of DELLAs might have impaired the biosynthesis, organization and/or homoeostasis of MT in root tip cells of A. thaliana seedlings, and this, in turn, might have caused the inhibition of cell elongation and the altered patterning of GL2 gene expression and of root hairs at the MZ and EZ of the root. In fact, the DELLAS destabilize the MT, giving rise to non-polar cell growth [LOCASCIO \& al. 2013].

In this respect, it is known that the levels of ploidy exert an important control over cell size, and that cell size and morphology are, in turn, linked to DNA content [KONDOROSI \& al. 2001]. Moreover, in many tissues, cell elongation is associated to the endo-reduplication of the DNA (replication without mitosis that occurs before cell elongation, resulting in a logarithmic accumulation of genome copies in each nucleus) [SANZ \& al. 2012]. Thus, the earliest morphological signs in trichome initiation are the induction of endo-reduplication and the increase in the nuclear and cellular size [PERAZZA \& al. 1998]. With this regard, it is known that GAs induce endo-reduplication in a dose-dependent manner and regulate cyclin gene expression. In fact, trichomes in the spy5 mutant have two times more DNA than WT trichomes [PERAZZA \& al. 1998; KONDOROSI \& al. 2001]. Moreover, in GA-deficient transgenic plants, the observed root swelling, due to MT disorganization, is associated to the induction and accumulation of cyclin CYC3;1 and CYCB1;1 proteins, because the DELLAs are involved in cell cycle progression [UBEDA-TOMÁS \& al. 2009; GOU \& al. 2010; SÁNCHEZCALDERÓN \& al. 2013]. In addition, the halting degree of the cell cycle is related to the GA endogenous level [LI \& al. 2015b]. Mutations in the $\alpha$-tubulin gene and drugs that inhibit MT polymerization also induce multi-nucleated cells [BAO \& al. 2001]. Interestingly, the control of endo-reduplication in trichomes participates in the regulation of epidermal patterning [PIETRA \& al. 2015], whereas the RHL genes, related to endo-reduplication, affect root epidermal cell fate independently from the GL2 gene network [GUO \& al. 2009].

Given that stress reduces root cell length and, thus, root length [DINNENY \& al. 2008], then, the morphological alterations that were observed in the root cells under excessive levels of DELLAs in 5-day-old $A$. thaliana seedlings might be in tune with the known role of these proteins as mediators of the plant Stress-Induced Morphogenic Responses (SIMR), which are characterized by changes in MT metabolism, CW flexibility and cell cycle progression [POTTERS \& al. 2007]. Moreover, it is known that stress inhibits growth by reducing GA levels and promoting the stabilization and accumulation of DELLAs [ACHARD \& GENSCHIK, 2009; ALONSO-RAMÍREZ \& al. 2009], and that the DELLAs mediate the SIMR associated to P deficiency [JIANG \& al. 2007]. From this, it might be hypothesized that an alteration of MT homoeostasis might have been implicated in the cell size changes that were observed in roots of 
A. thaliana seedlings grown under (or harbouring) excessive levels of GAs/DELLAs. While excessive levels of DELLAs might have disorganized the MT cytoskeleton, excessive levels of GAs might have stabilized it, giving rise to the changes of cell size and cell fate observed at the $\mathrm{MZ}$ and $\mathrm{EZ}$ of the root.

Results also suggest that cell fate decisions at the root epidermis might be synchronized with the cell size changes at the inner tissues of the root, such as the cortex. Thus, another reason for the appearance of extra root hairs in A. thaliana seedlings grown under (or harbouring) excessive levels of GAs/DELLAs might have been the reduction of the ratios of cortical/epidermal cell length (e.g. under excessive DELLAs, which decrease the cortex cell length) and of cortical/epidermal cell width (e.g. under excessive GAs, which decrease the cortex cell width), as they might give rise to epidermal cells laying over two cortical intersections instead of one, and, hence, to two-haired epidermal cells. This would imply that not only the length and width of epidermal cells, but also the length and width of cortical cells might contribute to the number of hairs produced by the root, although additional studies are needed to confirm this hypothesis.

On the other hand, results of this study also point at the cortex, endodermis and pericycle as root tissues from which the GAs/DELLAs might influence the root hair patterning, because transgenic lines over-expressing gai-1 at these root tissues produced ectopic root hairs and non-hairs [MCCARTHY-SUÁREZ, unpublished manuscript]. In fact, it has been shown that blocking GAs signalling at the root endodermis induces morphological defects in the root epidermal cells [LÖFKE \& al. 2013; PIETRA \& al. 2015; JANES \& al. 2018].

\section{Root cell number: Connections to the root hair patterning and abundance}

Excessive levels of GAs/DELLAs also altered the radial cell organization in root tips of seedlings of A. thaliana. While excessive levels of DELLAs frequently induced additional cells at the epidermis, cortex, endodermis and pericycle of the root, excessive levels of GAs sometimes induced extra cells at the root cortex and pericycle. With this respect, whether the cell proliferation at the root cortex-endodermis-pericycle under excessive levels of DELLAs was another reason for the observed disorganization in the root hair patterning [MCCARTHYSUÁREZ, unpublished manuscript], it might be worth confirming in future experiments by using inhibitors and/or mutants of cell division.

Regarding the epidermis, interestingly, the predicted number of cells at the Atrichoblast position per root radial section increased under excessive DELLAs (PAC, gai-1), but decreased under excessive GAs ( $5 X$ mutant) [MCCARTHY-SUÁREZ, unpublished manuscript]. Nevertheless, as the predicted number of cells at the Trichoblast position did not change, and the percentage of ectopic root hairs was higher under excessive DELLAs as compared to excessive GAs [MCCARTHY-SUÁREZ, unpublished manuscript], then, the higher abundance of root hairs seen under excessive DELLAs in comparison to excessive GAs was probably due to the induction of ectopic root hairs - and, thus, to the higher number of cells at the Atrichoblast position - and not because of the appearance of new Trichoblast positions, given that the number of cells at the Trichoblast position remained unchanged [MCCARTHYSUÁREZ, unpublished manuscript].

In fact, Arabidopsis increases root hair density in the radial dimension by increasing the number of epidermal cells that differentiate into root hair cells [JANES \& al. 2018]. An increased number of epidermal cells in the radial domain of the root has also been described under P deficiency and in tip1 mutants [MA \& al. 2001; GRIERSON \& SCHIEFELBEIN, 2002; MÜLLER \& SCHMIDT, 2004]. However, under P deficiency, the extra epidermal cells at the 
Iva MCCARTHY-SUÁREZ

Trichoblast position (up to 12) do not increase the abundance of root hairs in the radial axis as ectopic non-hairs also appear [MA \& al. 2001; JANES \& al. 2018]. Interestingly, a distorted radial patterning of root cells has also been described in mutants of WRKY75, a negative regulator of root hair formation [RISHMAWI \& al. 2014].

Radial proliferation of the root cortex cells has also been reported under stress (e.g. P deficiency) as well as in tip1, erh3 and $j k d$ mutants, all with an altered root hair patterning [MA \& al. 2001; MÜLLER \& SCHMIDT, 2004; HASSAN \& al. 2010; CUI, 2015; JANES \& al. 2018]. Periclinal cell divisions (extra layers) of the root cortex have equally been described in mutants of JKD, which acts from the root cortex to specify the patterning of epidermal cell types [WELCH \& al. 2007; LYER-PASCUZZI \& BENFEY, 2008; HASSAN \& al. 2010]. Interestingly, the GAs restrict the production of extra layers of cortex cells in Medicago truncatula roots, thereby generating thinner roots [FONOUNI-FARDE \& al. 2019]. In contrast, PAC treatments, or mutations in components of GA signalling, increase the number of layers of root cortex cells, that is, they induce a premature middle cortex (MC) [PAQUETTE \& BENFEY, 2005; CUI \& BENFEY, 2009]. Moreover, the GAs suppress the MC formation that is proper of the root responses to stress, whereas the DELLAs promote it [CUI \& BENFEY, 2009; FONOUNI-FARDE \& al. 2019]. Thus, the formation of a MC, due to random and periclinal cell divisions at the root endodermis, and that later on will acquire identity of root cortex, has been described under P deficiency [CUI \& BENFEY, 2009; JANES \& al. 2018]. Although the production of a MC has also been reported in roots of 3-day-old WT A. thaliana seedlings, the presence of a premature MC in the spy mutant, with high levels of GAs, suggests that imbalances in GAs/DELLAs homoeostasis, which can be triggered by stress, might bring about the formation of a MC [CUI \& BENFEY, 2009; CUI, 2015]. Maybe, this was the reason, in this study, for the presence of a MC in roots of $A$. thaliana seedlings grown under (or harbouring) excessive levels of GAs ( $1 \mu \mathrm{M} \mathrm{GA}_{4}$ and $\left.Q D\right)$ (Figures 5 and 6).

Because the PAC-inducible phenotype of MC is also present in the scr (scarecrow) and HDA mutants, as well as in trichostatin A (TSA)-treated plants, all producing ectopic root hairs [CUI \& BENFEY, 2009], then, a possible link between MC formation (or ectopic cell proliferation at the cortex/endodermis) and alteration of the root hair patterning might be established. Whether this contributed to the disorganisation of the root hair patterning observed under excessive levels of DELLAs, where a cell proliferation was equally observed at the cortex/endodermis/pericycle of the root, it is not known, but might be worth studying in future experiments by using cell division inhibitors and/or mutants. In fact, the alteration of the root hair patterning in the SCR::gai-1:GR mutant after growth in DEXA [MCCARTHY-SUÁREZ, unpublished manuscript] was accompanied by random and periclinal cell divisions at the root endodermis (Figure 3). Moreover, because the root MZ and EZ constitute cell fate-decision zones in Arabidopsis, then, any changes in cell division at tissues placed underneath the epidermis of the MZ/EZ might bring about changes in epidermal cell fate. In fact, the proliferation of cortex cells is known to influence the root epidermal patterning [LÖFKE et al. 2013; PIETRA \& al. 2015; JANES \& al. 2018]. Interestingly, histone deacetylation, which affects the root hair patterning, has a role in the proliferation of root cortex cells [XU \& al. 2005; LI \& al. 2015a]. Increases in the number of root endodermal cells have also been reported in erh mutants, during P deficiency, and in rhizobium-infected plants [MÜLLER \& SCHMIDT, 2004; MA \& al. 2001; JANES \& al. 2018]. The schizoriza (scz) mutant, in turn, has defects in the root radial patterning, with extra periclinal cell divisions that result in multiple layers of ground tissue (cortex and endodermis) [MYLONA \& al. 2002]. Thus, the results of this study suggest that the alterations in the root hair patterning of A. thaliana seedlings grown under 
excessive levels of GAs/DELLAs might also have been related to changes in the number of the cortical/endodermal/pericycle cells of the root.

Other possible cause, in this study, for the appearance of ectopic root hairs under excessive levels of GAs/DELLAs [MCCARTHY-SUÁREZ, unpublished manuscript] might have been the anticlinal, diagonal or asymmetric cell divisions (T-clones) frequently observed at the root epidermis, as they gave rise to changes in the GL2pro::GUS expression patterning and the size of daughter cells (Figure 3). These T-clones, in turn, might have been linked to alterations in the MT cytoskeleton, as MT are required for the correct positioning of cell division planes [SCHERES \& BENFEY, 1999; BAO \& al. 2001; RODRIGUEZ-SERRANO \& al. 2014]. Moreover, a reduced expression of the $\alpha$-tubulin gene impairs cell division and results in defects of tissue organization at the root tip [BAO \& al. 2001]. Also, the regulation of asymmetric cell divisions in plants is necessary for the generation of cell diversity and patterns [PERNAS \& al. 2010]. In fact, root hair cells are shorter than root non-hair cells, so that when an asymmetric cell division takes place at the epidermis of the MZ, the larger cell becomes the root non-hair cell [SALAZAR-HENAO \& al. 2016]. With this respect, it is known that the GAs induce cell proliferation at the root $\mathrm{MZ}$ and promote the division of epidermal cells [UBEDA-TOMÁS \& al. 2009; LEE \& al. 2012]. Furthermore, the DELLAs inhibit root cell division in the longitudinal dimension when mediating the SIMR associated to P deficiency [JIANG \& al. 2007; PÉRET \& al. 2011]. Interestingly, in a dwarf GA-deficient mutant, the MT exhibit an oblique orientation [BOUQUIN \& al. 2003]. Also, in the erh3 mutants, which act in the same route as $c p c$ and rhd6 (root hair defective 6), but independently from WER, the CW are disaligned, diagonally orientated, and malformed, that is, the positioning of the cell plates and the $\mathrm{CW}$ is abnormal, what indicates that ERH3 participates in orienting the cell plates during cytokinesis [WEBB \& al. 2002]. The cortex-associated SABRE protein is also involved in the orientation of cell division planes [PIETRA, 2014; PIETRA \& al. 2013, 2015]. In addition, GL2 is involved in the production of T-clones, whereas WER regulates cell proliferation, what suggests that genes that regulate the cell specification also regulate the cell division planes [LEE \& SCHIEFELBEIN, 1999; SCHERES \& al. 2002].

Thus, these results suggest that changes in cell number induced by excessive levels of GAs/DELLAs at the epidermis, cortex, endodermis and pericycle of the root tip in A. thaliana seedlings might influence the root hair patterning. Moreover, changes in cell number at tissues placed underneath the root epidermis might bring changes of cell fate at the root epidermal cells.

In addition, results of this study suggest that excessive levels of DELLAs in roots of $A$. thaliana seedlings might impair the biosynthesis and/or the assembly of MT, as judged by the swelling of the root tip cells (Figures 1-4), the presence of multi-nucleated cells at the MZ (Figure 6), and the occurrence of ectopic root hairs, branched root hairs, and cells with multiple root hairs [MCCARTHY-SUÁREZ, unpublished manuscript]. In fact, a reduced expression of the $\alpha$-tubulin gene results in the disassembly and aberrant reorganization of MT [BAO \& al. 2001]. This means that the alteration of the root hair patterning in A. thaliana seedlings by excessive levels of DELLAs might have been correlated to their inhibitory effect on MT organisation. In fact, MT are essential to stablish root cell identity in Arabidopsis [WEBB \& al. 2002]. 
The GAs/DELLAs might regulate the root architecture in A. thaliana seedlings

Excessive levels of DELLAs also promoted the outburst of LR near the root tip in $A$. thaliana seedlings, whereas excessive levels of GAs inhibited it. This means that any alteration in the levels of GAs/DELLAs might affect not only the root hair patterning, morphology and abundance, but also the root architecture. Thus, in seedlings of A. thaliana, physiologicallycontrolled levels of GAs/DELLAs might have a function in establishing a correct patterning and morphology of root hairs as well as in organising a proper root structure. In fact, supraphysiological levels of DELLAs mediate the root architecture changes that are associated to abiotic stress in plants (i.e., root elongation inhibition, root radial expansion, MC formation, pericycle cell proliferation and LR induction) [YIH \& CLARK, 1965; JIANG \& al. 2007; GOU \& al. 2010; MARTÍN-REJANO \& al. 2011; PÉRET \& al. 2011; CUI, 2015; WILD \& al. 2016]. For example, soil deficiencies of $\mathrm{P}, \mathrm{B}, \mathrm{Fe}$ or $\mathrm{NO}_{3}{ }^{-}$stimulate $\mathrm{LR}$ production, as nutrient concentration regulates LR production [YIH \& CLARK, 1965; HERMANS \& al. 2010; ZHANG \& al. 2014]. Early production of LR has also been reported in the erhl, jkd and arm mutants, equally with a shortened primary root [SCHNEIDER \& al. 1997; WELCH \& al. 2007]. Interestingly, LR formation, which initiates at the pericycle, is correlated to an alteration in actin and tubulin expression [PASTERNAK \& al. 2005; PÉRET \& al. 2011; SÁNCHEZCALDERÓN \& al. 2013]. Therefore, promoting LR outburst by increasing the local levels of DELLAs in roots might constitute a mechanism used by plants to increase the specific area of the root per mass unit, in a similar way as branched root hairs do.

\section{Conclusions}

As previously reported for other hormones, the results of this study, and of a previous one [MCCARTHY-SUÁREZ, unpublished manuscript] point to a possible role for the GAs/DELLAs in mediating the changes in the distribution, shape and frequency of root hairs, as well as in the configuration of the root, that take place in plants under situations of stress. Moreover, it is known that auxins, ET, ABA, BRs and SLs mediate these changes without altering the quantitative expression of WER and GL2 [SCHIEFELBEIN, 2003; YANG \& al. 2007; MARTÍN-REJANO \& al. 2011]. This implies that, by regulating the elongation and/or division of root cells, as well as the production of LR, the GAs/DELLAs might contribute to mediating the changes in the patterning, morphology and abundance of root hairs, and the root architecture adaptations, that occur in plants under environmental stress conditions.

\section{Notes on contributors}

Iva MCCARTHY-SUÁREZ - is a postdoctoral researcher in plant biology with special interest in the mechanism of action of plant hormones, senescence and environmental stress.

\section{Acknowledgements}

Special thanks to Dr. Miguel Ángel Blázquez and Dr. David Alabadí for supporting the writing of this paper. This study was performed at the blázquez-alabadí Laboratory (Hormone Signalling and Plant Plasticity Group, Instituto de Biología Celular y Molecular de Plantas (IBMCP)-CSIC-UPV, Valencia, Spain). Thanks also to Mrs. Marisol Gascón Irún for confocal microscope technical support. I. McCarthy Suárez also acknowledges a JAE-Doc postdoctoral fellowship (2008-2011), CSIC, Valencia, Spain. This paper is dedicated to the loving memory of Dr. Francisco Culiáñez-Macià, Principal Investigator at the IBMCP-UPV-CSIC, Valencia, Spain. 


\section{References}

ACHARD P. \& GENSCHIK P. 2009. Releasing the brakes of plant growth: how GAs shutdown DELLA proteins. Journal of Experimental Botany. 60(4): 1085-1092. https://doi.org/10.1093/jxb/ern301

ALONSO-RAMÍREZ A., RODRÍGUEZ D., REYES D., JIMÉNEZ J. A., NICOLÂS G., LÓPEZ-CLIMENT M., GÓMEZ-CÁRDENAS A. \& NICOLÁS C. 2009. Evidence for a role of gibberellins in salicylic acidmodulated early plant responses to abiotic stress in Arabidopsis seeds. Plant Physiology. 150(3): 1335-1344. https://doi.org.10.1104/pp.109.139352

BAHIN E., BAILLY C., SOTTA B., KRANNER I., CORBINEAU F. \& LEYMARIE J. 2011. Crosstalk between reactive oxygen species and hormonal signalling pathways regulates grain dormancy in barley. Plant, Cell \& Environment. 34(6): 980-993. https://doi.org.10.1111/j.1365-3040.2011.02298.x

BALUŠKA F., JASIK J., EDELMANN H. G., SALAJOVÁ T. \& VOLKMANN D. 2001. Latrunculin B-induced plant dwarfism: plant cell elongation is F-actin dependent. Developmental Biology. 231: 113-124. https://doi.org.10.1006/dbio.2000.0115

BAND L. R., UBEDA-TOMÁS S., DYSON R. J., MIDDLETON A. M., HODGMAN C., OWEN M. R., JENSEN O. E., BENNETT M. J. \& KING J. R. 2012. Growth-induced hormone dilution can explain the dynamics of plant root cell elongation. Proceedings of the National Academy of Sciences. 109(19): 7577-7582. https://doi.org/10.1073/pnas.1113632109

BAO Y., KOST B. \& CHUA N. H. 2001. Reduced expression of $\alpha$-tubulin genes in Arabidopsis thaliana specifically affects root growth and morphology, root hair development and root gravitropism. Plant Journal. 28(2): 145157. https://doi.org/10.1046/j.1365-313x.2001.01142.x

BENFEY P. N., LINSTEAD P. J., ROBERTS K., SCHIEFELBEIN J. W., HAUSER M. T. \& AESBACHER R. A. 1993. Root development in Arabidopsis: Four mutants with dramatically altered root morphogenesis. Development. 119(1): 57-70.

BOUQUIN T., MATTSON O., NAESTED H., FOSTER R. \& MUNDY J. 2003. The Arabidopsis lue1 mutant defines a katanin p60 ortholog involved in hormonal control of microtubule orientation during cell growth. Journal of Cell Science. 116(Pt 5): 791-801. https://doi.org/10.1242/jcs.00274

BURK D. H. \& YE Z. H. 2002. Alteration of oriented deposition of cellulose microfibrils by mutation of a katanin-like microtubule severing protein. Plant Cell. 14(9): 2145-2160. https://doi.org/10.1105/tpc.003947

CAO X. F., LINSTEAD P., BERGER F., KIEBER J. \& DOLAN L. 1999. Differential ethylene sensitivity of epidermal cells is involved in the establishment of cell pattern in the Arabidopsis root. Physiologiae Plantarum. 106(6): 311-317. https://doi.org/10.1034/j.1399-3054.1999.106308.x

CHEN C. Y., WU K. \& SCHMIDT W. 2015. The histone deacetylase HDA19 controls root cell elongation and modulates a subset of phosphate starvation responses in Arabidopsis. Science Reports. 5: 15708. https://doi.org/10.1038/srep15708

CHIEN J. C. \& SUSSEX I. M. 1996. Differential regulation of trichome formation on the adaxial and abaxial surfaces by gibberellins and photoperiod in Arabidopsis thaliana (L.) Heynh. Plant Physiology. 111(4): 1321-1328. https://doi.org/10.1104/pp.111.4.1321

COLLINGS D. A., LILL A. W., HIMMELSPACH R. \& WASTENEYS G. O. 2006. Hypersensitivity to cytoskeletal antagonists demonstrates microtubule-microfilament cross-talk in the control of root elongation in Arabidopsis thaliana. New Phytologist. 170(2): 275-290. https://doi.org/10.1111/j.1469.8137.2006.01671.x

CUI H. 2015. Cortex proliferation in the root is a protective mechanism against abiotic stress. Plant Signalling \& Behaviour. 10(5): e1011949. https://doi.org/10.1080/15592324

CUI H. \& BENFEY P. 2009. Interplay between scarecrow, GA and like heterochromatin protein 1 in ground tissue patterning in the Arabidopsis root. Plant Journal. 58(6): 1016-1027. https://doi.org/10.1111/j.1365313X.2009.03839.x

DINNENY J. R., LONG T. A., WANG J. Y., JUNG J. W., MACE D., POINTER S., BARRON C., BRADY S. M., SCHIEFELBEIN J. \& BENFEY P. N. 2008. Cell identity mediates the responses of Arabidopsis roots to abiotic stress. Science. 320(5878): 942-945. https://doi.org/10.1126/science.1153795

DUGARDEYN J. \& VAN DER STRAETEN D. 2008. Ethylene: Fine tuning plant growth and development by stimulation and inhibition of elongation. Plant Science. 175(1-2): 59-70. https://doi.org/10.1016/j.plantsci.2008.02.003

FONOUNI-FARDE C., MIASSOD A., LAFFONT C., MORIN H., BENDAHMANE A., DIET A. \& FRUGIER F. 2019. Gibberellins negatively regulate the development of Medicago truncatula root system. Science Reports. 9: 2335. https://doi.org/10.1038/s41598-019-38876-1

GARDINER J., COLLINGS D. A., HARPER J. D. I. \& MARC J. 2003. The effects of the phospholipase D- antagonist 1-butanol on seedlings development and microtubule organisation in Arabidopsis. Plant Cell Physiology. 44(7): 687-696. https://doi.org/10.1093/pcp/pcg095 
GENDRE D., BARAL A., DANG X., ESNAY N., BOUTTÉ Y., STANISLAS T., VAIN T., CLAVEROL S., GUSTAVSSON A., LIN D., GREBE M. \& BHALERAO R. P. 2019 Rho-of-plant activated root hair formation requires Arabidopsis YIP4a/b gene function. Development. 146(5): dev168559. https://doi.org/10.1242/dev.168559

GOU J., STRAUSS S. H., TSAI C. J., FANG K., CHEN Y., JIANG X. \& BUSOV V. B. 2010. Gibberellins regulate lateral root formation in Populus through interactions with auxin and other hormones. Plant Cell. 22(3): 623639. https://doi.org/10.1105/tpc.109.073239

GRIERSON C. \& SCHIEFELBEIN J. 2002. Root hairs. pp 2-22. In: SOMERVILLE C. R. \& MEYEROWITZ E. M. (eds). The Arabidopsis book. American Society of Plant Biologists, Rockville, MD.

GUO K., KONG W. W. \& YANG Z. M. 2009. Carbon monoxide promotes root hair development in tomato. Plant Cell \& Environment. 32(8): 1033-1045. https://doi.org/10.1111/j.1365-3040.2009.01986.x

HASSAN H., SCHERES B. \& BLILOU I. 2010. Jackdaw controls epidermal patterning in the Arabidopsis root meristem through a non-cell autonomous mechanism. Development. 137(9): 1523-1529. https://doi.org/10.1242/dev.048777

HERMANS C., PORCO S., VERBRUGGEN N. \& BUSH D. R. 2010. Chitinase-like protein CTL-1 plays a role in altering root system architecture in response to multiple environmental conditions. Plant Physiology. 152(2): 904-917. https://doi.org/10.1104/pp.109.149849

JANES G., VON WANGENHEIM D., COWLING S., KERR I., BAND L., FRENCH A. P. \& BISHOP A. 2018. Cellular patterning of Arabidopsis roots under low phosphate conditions. Frontiers in Plant Science. 9: 735. https://doi.org/10.3389/fpls.2018.00735

JANKAY P. \& MULLER W. H. 1976. The relationship among umbelliferone, growth, and peroxidase levels in cucumber roots. American Journal of Botany. 63(1): 126-132. https://doi.org/10.2307/2441675

JIANG C., GAO X., LIAO L., HARBERD N. P. \& FU X. 2007. Phosphate starvation, root architecture and anthocyanin accumulation responses are modulated by the gibberellin-DELLA signalling pathway in Arabidopsis. Plant Physiology. 145(4): 1460-1470. https://doi.org/10.1104/pp.107.103788

KAPPUSAMY K. T., CHEN A. Y. \& NEMHAUSER J. L. 2009. Steroids are required for epidermal cell fate establishment in Arabidopsis roots. Proceedings of the National Academy of Sciences. 106(19): 8073-8076. https://doi.org/10.1073/pnas.0811633106

KOMORISONO M., UEGUCHI-TANAKA M., AICHI I., HASEGAWA Y., ASHIKARI M., KITANO H., MATSUOKA M. \& SAZUKA T. 2005. Analysis of the rice mutant dwarf and gladius leaf1. Aberrant katanin-mediated microtubule organization causes up-regulation of gibberellin biosynthetic genes independently of gibberellin signalling. Plant Physiology. 138(4): 1982-1993. https://doi.org/10.1104/pp.105.062968

KONDOROSI E., ROUDIER F. \& GENDREAU E. 2001. Plant cell size control: growing by ploidy? Current Opinion in Plant Biology. 3(6): 488-492. https://doi.org/10.1016/s1369-5266(00)00118-7

LEE M. M. \& SCHIEFELBEIN J. 1999. WEREWOLF, a MYB-related protein in Arabidopsis, is a position-dependent regulator of epidermal cell patterning. Cell. 99 (5): 473-483. https://doi.org/10.1016/s0092-8674(00)81536-6

LEE L. Y., HOU X., FANG L., FANG S., KUMAR P. P. \& YU H. 2012. Stunted mediates the control of cell proliferation by GA in Arabidopsis. Development. 139(9): 1568-1576. https://doi.org/10.1242/dev.079426

LI D. X., CHEN W. Q., XU Z. H. \& BAI S. N. 2015a. HISTONE DEACETILASE6-Defective mutants show increased expression and acetylation of enhancer of tryptychon and caprice1 and glabra2 with small but significant effects on root epidermis cellular pattern. Plant Physiology. 168(4): 1448-1458. https://doi.org/10.1104/pp.15.00821

LI J., ZHAO Y., CHU H., WANG L., FU Y., LIU P., UPADHYAYA N., CHEN C., MOU T., FENG Y., KUMAR P. \& XU J. 2015b. Shoebox modulates root meristem size in rice through dose-dependent effects of gibberellins on cell organisation and proliferation. PLoS Genetics. 11(8): e1005464. https://doi.org/10.1371/journal.pgen.1005464

LIN D., CAO L., ZHOU Z., ZHU L., EHRHARDT D., YANG Z. \& FU Y. 2013. Rho GTPase signalling activates microtubule severing to promote microtubule ordering in Arabidopsis. Current Biology. 23(4): $290-297$. https://doi.org/10.1016/j.cub.2013.01.022

LIU Q. Y., GUO G. S., QIU Z. F., LI X. D., ZENG B. S. \& FAN C. J. 2018. Exogenous GA 3 application altered morphology, anatomic and transcriptional regulatory networks of hormones in Eucalyptus grandis. Protoplasma. 255(4): 1107-1119. https://doi.org/10.1007/s00709-018-1218-0

LOCASCIO A., BLÁZQUEZ M. A. \& ALABADÍ D. 2013. Dynamic regulation of cortical microtubule organization through prefoldin-DELLA interaction. Current Biology. 23(9): 804-809. https://doi.org/10.1016/j.cub.2013.03.053

LÖFKE C., DÜNSTER K. \& KLEINE-VEHN J. 2013. Epidermal patterning genes impose non-cell autonomous cell size determination and have additional roles in root meristem size control. Journal of Integrative Plant Biology. 55(9): 864-875. https://doi.org/10.1111/jipb.12097 


\section{SUPRA-PHYSIOLOGICAL LEVELS OF GIBBERELLINS / DELLAS MODIFY ROOT CELL SIZE...}

LOMBARDO M. C., GRAZIANO M., POLACCO J. C. \& LAMATTINA L. 2006. Nitric oxide functions as a positive regulator of root hair development. Plant, Signalling \& Behaviour. 1(1): 28-33. https://doi.org/10.4161/psb.1.1.2398

LYER-PASCUZZI A. \& BENFEY P. N. 2008. Transcriptional networks in root cell fate specification. Biochimica Biophysica Acta. 1789(4): 315-325. https://doi.org/10.1016/j.bbagrm.2008.09.006

MA Z., BIELENBERG G. D., BROWN K. M. \& LYNCH J. P. 2001. Regulation of root hair density of phosphorus availability in Arabidopsis thaliana. Plant, Cell \& Environment. 24(4): 459-467. https://doi.org/10.1046/j.1365-3040.2001.00695.x

MARTÍN-REJANO E. M., CAMACHO-CRISTÓBAL J. J., HERRERA-RODRÍGUEZ M. B., REXACH J., NAVARRO- GOCHICOA M. T. \& GONZÁLEZ-FONTES A. 2011. Auxin and ethylene are involved in the responses of root system architecture to low boron supply in Arabidopsis seedlings. Physiologiae Plantarum. 142(2): 170-178. https://doi.org/10.1111/j.1399-3054.2011.01459.x

MYLONA P., LINSTEAD P., MARTIENSSEN R. \& DOLAN L. 2002. Schizoriza controls an asymmetric cell division and restricts epidermal identity in the Arabidopsis root. Development. 129(18): 4327-4334. https://doi.org/10.1242/dev.129.18.4327

MÜLLER M. \& SCHMIDT W. 2004. Environmentally induced plasticity of root hair development in Arabidopsis. Plant Physiology. 134(1): 409-419. https://doi.org/10.1104/pp.103.029066

NAGATA T., TODORIKI S. \& KIKUCHI S. 2004. Radial expansion of root cells and elongation of root hairs of Arabidopsis thaliana induced by massive doses of gamma irradiation. Plant Cell Physiology. 45(11): 1557 1565. https://doi.org/10.1093/pcp/pch178

NELISSEN H., RYMEN B., JIKUMARU Y., DEMUYNCK K., VAN LIJSEBETTENS M., KAMIYA Y., INZÉ D. \& BEEMSTER G. T. S. 2012. A local maximum in gibberellin levels regulates maize leaf growth by spatial control of cell division. Current Biology. 22(13): 1183-1187. https://doi.org/10.1016/j.cub.2012.04.065

NIU Y., JIN C., JIN G., ZHOU Q., LIN X., TANG C. \& ZHANG Y. 2011. Auxin modulates the enhanced development of root hairs in Arabidopsis thaliana (L.) Heyhn. under elevated CO(2). Plant, Cell \& Environment. 34(8): 1304-1317. https://doi.org/10.1111/j.1365-3040.2011.02330.x

OHASHI Y., OKA A., RODRÍGUES-POUSADA R., POSSENTI M., RUBERTI I., MORELLI G. \& AOYAMA T. 2003. Modulation of phospholipid signalling by GLABRA2 in root hair pattern formation. Science. 300(5624): 1427-1430. https://doi.org/10.1126/science.1083695

PAQUETTE A. J. \& BENFEY P. N. 2005. Maturation of the ground tissue of the root is regulated by gibberellin and SCARECROW and requires SHORT-ROOT. Plant Physiology. 138(2): 636-640. https://doi.org/10.1104/pp.104.058362

PASTERNAK T., POTTERS G., CAUBERGS R. \& JANSEN M. A. K. 2005 Complementary interactions between oxidative stress and auxins control plant growth responses at plant, organ and cellular level. Journal of Experimental Botany. 56(418): 1991-2001. https://doi.org/10.1093/jxb/eri196

PERAZZA D., VACHON G. \& HERZOG M. 1998. Gibberellins promote trichome formation by up-regulating GLABROUS1 in Arabidopsis. Plant Physiology. 117(2): 375-383. https://doi.org/10.1104/pp.117.2.375

PÉRET B., CLÉMENT M., NUSSAUME L. \& DESNOS T. 2011. Root developmental adaptation to phosphate starvation: Better safe than sorry. Trends in Plant Sciences. 16(8): 442-450. https://doi.org/10.1016/j.tplants.2011.05.006

PERNAS M., RYAN E. \& DOLAN L. 2010. Schizoriza controls tissue system complexity in plants. Current Biology. 2(9): 818-823. https://doi.org/10.1016/j.cub.2010.02.062

PIETRA S. 2014. Characterization of new players in planar polarity establishment in Arabidopsis. PhD thesis. Umea Plant Science Centre Fysiologisk Botanik, Sweden.

PIETRA S., GUSTAVSSON A., KIEFER C., KALMBACH L., HÖRSTEDT P., IKEDA Y., STEPANOVA A. N., ALONSO J. M. \& GREBE M. 2013. Arabidopsis SABRE and CLASP interact to stabilize cell division plane orientation and planar polarity. Nature Communications. 4: 2779. https://doi.org/10.1038/ncomms3779

PIETRA S., LANG P. \& GREBE M. 2015. SABRE is required for stabilization of root hair patterning in Arabidopsis thaliana. Physiologiae Plantarum. 153(3): 440-453. https://doi.org/10.1111/ppl.12257

POTTERS G., PASTERNAK T. P., GUISEZ Y., PALME K. J. \& JANSEN M. A. K. 2007 Stress-induced morphogenic responses: Growing out of trouble? Trends in Plant Science. 12(3): 98-105. https://doi.org/10.1016/j.tplants.2007.01.004

RISHMAWI L., PESCH M., JUENGST C., SCHAUSS A. C., SCHRADER A. \& HÜLSKAMP M. 2014. Non-cell autonomous regulation of root hair patterning genes by WRKY75 in Arabidopsis. Plant Physiology. 165(1): 186-195. https://doi.org/10.1104/pp.113.233775

RODRÍGUEZ-SERRANO M., PAZMIÑO D. M., SPARKES I., ROCHETTI A., HAWES C., ROMERO-PUERTAS M. C. \& SANDALIO L. M. 2014. 2,4-dichlorophenoxyacetic acid promotes S-nitrosylation and oxidation of actin affecting cytoskeleton and peroxisomal dynamics. Journal of Experimental Botany. 65(17): 47834793. https://doi.org/10.1093/jxb/eru237 
SALAZAR-HENAO J. E., VÉLEZ-BERMÚDEZ I. C. \& SCHMIDT W. 2016. The regulation and plasticity of root hair patterning and morphogenesis. Development. 143(11): 1848-1858. https://doi.org/10.1242/dev.132845

SÁNCHEZ-CALDERÓN L., IBARRA-CORTÉS M. E. \& ZEPEDA-JAZO I. 2013. Root development and abiotic stress adaptation. pp. 135-168. In: VAHDATI K. \& LESLIE C. (eds). Abiotic stress-plant responses and applications in agriculture. Intech Open Science, London.

SANZ L., MURRAY J. A. H. \& DEWITTE W. 2012. To divide and to rule: Regulating cell division in roots during post-embryonic growth. Progress in Botany. 73: 57-80. https://doi.org/10.1007/978-3-642-22746-2_2

SCHERES B. \& BENFEY P. N. 1999. Asymmetric cell division in plants. Annual Review of Plant Physiology and Plant Molecular Biology. 50: 505-537. https://doi.org/10.1146/annurev.arplant.50.1.505

SCHERES B., BENFEY P. \& DOLAN L. 2002. Root development. pp. 2-18. In: SOMERVILLE C. R. \& MEYEROWITZ E. M. (eds). The Arabidopsis book. American Society of Plant Biologists, Rockville, MD.

SCHIEFELBEIN J. 2003. Cell fate specification in the epidermis: A common patterning mechanism in the root and the shoot. Current Opinion in Plant Biology. 6(1): 74-78. https://doi.org/10.1016/S136952660200002X

SCHIEFELBEIN J., MASUCCI J. D. \& WANG H. 1997. Building a root: The control of patterning and morphogenesis during root development. Plant Cell. 9(7): 1089-1098. https://doi.org/10.1105/tpc.9.7.1089

SCHMIDT W., TITTEL J. \& SCHIKORA A. 2000. Role of hormones in the induction of iron deficiency responses in Arabidopsis roots. Plant Physiology. 122(4): 1109-1118. https://doi.org/10.1104/pp.122.4.1109

SCHNEIDER K., WELLS B., DOLAN L. \& ROBERTS K. 1997. Structural and genetic analysis of epidermal cell differentiation in Arabidopsis primary roots. Development. 124(9): 1789-1798.

SHANI E., WEINSTAIN R., ZHANG Y., CASTILLEJO C., KAISERLI E., CHORY J., TSIEN R. Y. \& ESTELLE M. 2013. Gibberellins accumulate in the elongating endodermal cells of Arabidopsis root. Proceedings of the National Academy of Sciences. 110(12): 4834-4839. https://doi.org/10.1073/pnas.1300436110

SHIN L. J., HUANG H. E., CHANG H., LIN Y. N., FENG T. Y. \& GER M. J. 2011. Ectopic ferredoxin I protein promotes root hair growth through induction of reactive oxygen species in Arabidopsis thaliana. Journal of Plant Physiology. 168(5): 434-440. https://doi.org/10.1016/j.jplph.2010.08.002

TRAW M. B. \& BERGELSON J. 2003. Interactive effects of jasmonic acid, salicylic acid, and gibberellin on induction of trichomes in Arabidopsis. Plant Physiology. 133(3): 1367-1375. https://doi.org/10.1104/pp.103.027086

UBEDA-TOMÁS S., SWARUP R., COATES J., SWARUP K., LAPLACE L., BEEMSTER G. T. S, HEDDEN P., BHALERAO R. \& BENNETT M. J. 2008. Root growth in Arabidopsis requires gibberellin/DELLA signalling in the endodermis. Nature Cell Biology. 10(5): 625-628. https://doi.org/10.1038/ncb1726

UBEDA-TOMÁS S., FEDERICI F., CASIMIRO I., BEEMSTER G. T. S., BHALERAO R., SWARUP R., DOERNER P., HASELHOFF J. \& BENNETT M. J. 2009. Gibberellin signalling in the endodermis controls Arabidopsis root meristem size. Current Biology. 19(14): 1194-1199. https://doi.org/10.1016/j.cub.2009.06.023

VAN HENGEL A. J., BARBER C. \& ROBERTS K. 2004. The expression patterns of arabinogalactan-protein AtAGP30 and GLABRA2 reveal a role for abscisic acid in the early stages of root epidermal patterning. Plant Journal. 39(1): 70-83. https://doi.org/10.1111/j.1365-313X.2004.02104.x

WANG G. L., QUE F., XU Z. S., WANG F. \& XIONG A. S. 2015. Exogenous gibberellin altered morphology, anatomic and transcriptional regulatory networks of hormones in carrot root and shoot. BMC Plant Biology. 15: 290. https://doi.org/10.1186/s12870-015-0679-y

WEBB M., JOUANNIC S., FOREMAN J., LINSTEAD P. \& DOLAN L. 2002. Cell specification in the Arabidopsis root epidermis requires the activity of ECTOPIC ROOT HAIR 3 - a katanin-P60 protein. Development. 129(1): 123-131.

WELCH D., HASSAN H., BLILOU I., IMMINK R., HEIDSTRA R. \& SCHERES B. 2007. Arabidopsis JACKDAW and MAGPIE zinc finger proteins delimit asymmetric cell division and stabilize tissue boundaries by restricting SHORT-ROOT action. Genes Development. 21(17): 2196-2204. https://doi.org/10.1101/gad.440307

WILD M., DAVIÈRE J. M., REGNAULT T., SAKVARELIDZE-ACHARD L., CARRERA E., LOPEZ-DIAZ I., CAYREL A., DUBEAUX G., VERT G. \& ACHARD P. 2016. Tissue-specific regulation of gibberellin signalling fine-tunes Arabidopsis iron-deficiency responses. Developmental Cell. 37(2): 190-200. https://doi.org/10.1016/j.devcel.2016.03.022

XU C. R., LIU C., WANG Y. L., LI L. C., CHEN W. Q., XU Z. H. \& BAI S. N. 2005. Histone deacetylation affects expression of cellular patterning genes in the Arabidopsis root epidermis. Proceedings of the National Academy of Sciences. 102(40): 14469-14474. https://doi.org/10.1073/pnas.0503143102

YANG T., SAVAGE N. \& SCHMIDT W. 2007. Plasticity of root epidermal cell fate in response to nutrient starvation. 18th International Conference on Arabidopsis Research. TAIR accession publication [online]: 501721882 [accessed Aug. 23 ${ }^{\text {rd }}, 2021$ ].

YIH R. Y. \& CLARK H. E. 1965. Carbohydrate and protein content to boron-deficient tomato root tips in relation to anatomy and growth. Plant Physiology. 40(2): 312-315. https://doi.org/10.1104/pp.40.2.312 
ZHANG C., BOUSQUET A. \& HARRIS J. M. 2014. Abscisic acid and lateral root organ defective/numerous infections and polyphenolics modulate root elongation via reactive oxygen species in Medicago truncatula. Plant Physiology. 166(2): 644-658. https://doi.org/10.1104/pp.114.248542

\section{How to cite this article:}

McCARTHY-SUÁREZ I. 2021. Supra-physiological levels of gibberellins / DELLAs modify root cell size / number and root architecture in root tips of $A$. thaliana seedlings. Connections to the root hair patterning and abundance. J. Plant Develop. 28: 69-96. https://doi.org/10.47743/jpd.2021.28.1.887 